\title{
Sequential assimilation of satellite-derived vegetation and soil moisture products using SURFEX_v8.0: LDAS-Monde assessment over the Euro-Mediterranean area
}

\author{
Clément Albergel ${ }^{1}$, Simon Munier ${ }^{1}$, Delphine Jennifer Leroux ${ }^{1}$, Hélène Dewaele ${ }^{1}$, David Fairbairn ${ }^{1, a}$, \\ Alina Lavinia Barbu ${ }^{1}$, Emiliano Gelati ${ }^{1, b}$, Wouter Dorigo ${ }^{2}$, Stéphanie Faroux ${ }^{1}$, Catherine Meurey ${ }^{1}$, \\ Patrick Le Moigne $^{1}$, Bertrand Decharme ${ }^{1}$, Jean-Francois Mahfouf ${ }^{1}$, and Jean-Christophe Calvet ${ }^{1}$ \\ ${ }^{1}$ CNRM UMR 3589, Météo-France/CNRS, Toulouse, France \\ ${ }^{2}$ Department of Geodesy and Geo-Information, TU Wien (Vienna University of Technology), Vienna, Austria \\ ${ }^{a}$ now at: European Centre for Medium-Range Weather Forecasts, Reading, UK \\ ${ }^{b}$ now at: Joint Research Centre, European Commission, Ispra, Italy
}

Correspondence to: Clément Albergel (clement.albergel@meteo.fr)

Received: 17 May 2017 - Discussion started: 30 May 2017

Revised: 17 August 2017 - Accepted: 8 September 2017 - Published: 25 October 2017

\begin{abstract}
In this study, a global land data assimilation system (LDAS-Monde) is applied over Europe and the Mediterranean basin to increase monitoring accuracy for land surface variables. LDAS-Monde is able to ingest information from satellite-derived surface soil moisture (SSM) and leaf area index (LAI) observations to constrain the interactions between soil-biosphere-atmosphere (ISBA, Interactions between Soil, Biosphere and Atmosphere) land surface model (LSM) coupled with the CNRM (Centre National de Recherches Météorologiques) version of the Total Runoff Integrating Pathways (ISBA-CTRIP) continental hydrological system. It makes use of the $\mathrm{CO}_{2}$-responsive version of ISBA which models leaf-scale physiological processes and plant growth. Transfer of water and heat in the soil rely on a multilayer diffusion scheme. SSM and LAI observations are assimilated using a simplified extended Kalman filter (SEKF), which uses finite differences from perturbed simulations to generate flow dependence between the observations and the model control variables. The latter include LAI and seven layers of soil (from 1 to $100 \mathrm{~cm}$ depth). A sensitivity test of the Jacobians over 2000-2012 exhibits effects related to both depth and season. It also suggests that observations of both LAI and SSM have an impact on the different control variables. From the assimilation of SSM, the LDAS is more effective in modifying soil moisture (SM) from the top layers of soil, as model sensitivity to SSM decreases with depth and has almost no impact from $60 \mathrm{~cm}$
\end{abstract}

downwards. From the assimilation of LAI, a strong impact on LAI itself is found. The LAI assimilation impact is more pronounced in SM layers that contain the highest fraction of roots (from 10 to $60 \mathrm{~cm}$ ). The assimilation is more efficient in summer and autumn than in winter and spring. Results shows that the LDAS works well constraining the model to the observations and that stronger corrections are applied to LAI than to SM. A comprehensive evaluation of the assimilation impact is conducted using (i) agricultural statistics over France, (ii) river discharge observations, (iii) satellite-derived estimates of land evapotranspiration from the Global Land Evaporation Amsterdam Model (GLEAM) project and (iv) spatially gridded observationbased estimates of upscaled gross primary production and evapotranspiration from the FLUXNET network. Comparisons with those four datasets highlight neutral to highly positive improvement.

\section{Introduction}

Land surface models (LSMs) forced by gridded atmospheric variables and their coupling with river routing models are important for understanding the terrestrial water and vegetation cycles (Dirmeyer et al., 2006). These LSMs need to simulate biogeophysical variables such as surface, root zone soil 
moisture (SSM and RZSM, respectively) and leaf area index (LAI) in a way that is fully consistent with the representation of surface and energy flux and river discharge simulations. Soil moisture (SM) is an essential component in partitioning incoming water and energy over land, thus affecting the variability of evapotranspiration, runoff and energy fluxes (Mohr et al., 2000). By controlling land surface temperature, plant water stress, evapotranspiration and infiltration of precipitation, soil moisture drives ecosystem dynamics, biodiversity and food production; regulates $\mathrm{CO}_{2}$ emissions (uptake) from the land surface; and impacts natural hazards such as floods and droughts (Seneviratne et al., 2010). The role of soil moisture as a regulator for various processes in the terrestrial ecosystem such as plant phenology, photosynthesis, biomass allocation and soil respiration, and hence the terrestrial carbon balance, has also clearly been established (Ciais et al., 2005; Van der Molen et al., 2012; Carvalhais et al., 2014; Reichstein et al., 2013). The seasonal dynamics of vegetation properties, such as LAI, are connected to soil moisture dynamics (Kochendorfer and Ramirez, 2010). Both the simulation of hydrological processes and the exchange of water vapour and $\mathrm{CO}_{2}$ between the vegetation canopy and atmosphere interface are strongly influenced by LAI (Jarlan et al., 2008; Szczypta et al., 2014).

Global observations of land surface variables are now operationally available from spaceborne instruments and they can be used to constrain LSMs through data assimilation (DA) techniques as demonstrated by several authors (e.g. Reichle et al., 2002; Draper et al., 2011, 2012; Dharssi et al., 2011; Barbu et al., 2011; de Rosnay et al., 2013, 2014; Barbu et al., 2014; Boussetta et al., 2015; Fairbain et al., 2017). Recent studies (e.g. Traore et al., 2014) have demonstrated that a model that performs best for soil moisture does not necessarily perform best for plant productivity, highlighting the need to jointly use soil moisture and vegetation observations to improve global and continental eco-hydrological and/or carbon cycle models (Wang et al., 2012; Kaminski et al., 2013). Several studies demonstrated the benefit of jointly assimilating SSM and LAI on the representation of RZSM (e.g. Sabater et al., 2008) and $\mathrm{CO}_{2}$ flux (e.g. Albergel et al., 2010; Barbu et al., 2011).

Within the SURFEX modelling system (SURFace EXternalisée, Masson et al., 2013) the $\mathrm{CO}_{2}$-responsive version of the ISBA (Interaction Sol-Biosphère-Atmosphère: interaction between soil-biosphere-atmosphere) LSM (Noilhan and Mahfouf, 1996; Calvet et al., 1998, 2004; Gibelin et al., 2006) allows the representation of various land surface processes, including evapotranspiration and SM evolution. It is also capable of modelling photosynthesis and vegetation growth. The evolution of the simulated LAI and vegetation biomass changes in response to the meteorological forcing conditions. In previous studies, Barbu et al. (2014) and Fairbairn et al. (2017) tested a combined assimilation of SSM and LAI in this $\mathrm{CO}_{2}$-responsive version of ISBA over France within SURFEX. They used the force-restore version of ISBA (with three layers of soil), a simplified formulation of an extended Kalman filter (SEKF) with a $24 \mathrm{~h}$ assimilation window and hourly meteorological forcing from the SAFRAN reanalysis (Système d'Analyse Fournissant des Renseignements Atmosphériques à la Neige, QuintanaSeguret al., 2008; Habets et al., 2008) on an 8 km scale. Fairbairn et al. (2017), also made a posterior offline use of runoff and drainage fields from ISBA to run the MODCOU hydrological model (MODèle COUplé, Habets et al., 2008) to evaluate the added value of the joint assimilation of LAI and SSM on the representation of river discharge over France. However, the assimilation was not successful in improving the representation of river discharge within MODCOU compared to an open-loop (i.e. no assimilation) simulation. Following their work, the present study tests the assimilation of both satellite-derived SSM and LAI on the continental scale. Further steps are made by the following:

- using the most recent SURFEX_v8.0 Offline Data Assimilation implementation;

- considering a much larger domain (Europe and the Mediterranean basin) as well as a longer time period, 2000-2012;

- using the multi-layer soil diffusion scheme of ISBA developed by Decharme et al. (2011).

- assimilating a long-term, global-scale, multi-sensor and satellite-derived surface soil moisture dataset (ESA CCI SSM, Liu et al., 2011, 2012; Dorigo et al., 2015, 2017) along with satellite-derived LAI (GEOV1, http://land. copernicus.eu/global/);

- using the modified version of the WFDEI (WATCHForcing-Data-ERA-Interim) observation-based atmospheric forcing dataset (Weedon et al., 2011, 2014) from the eartH2Observe project (Schellekens et al., 2017);

- having a daily interactive coupling between ISBA and the CNRM (Centre National de Recherches Météorologiques) version of the TRIP (Total Runoff Integrating Pathways, Oki et al., 1998) river routing model (CTRIP hereafter) to simulate hydrological variables such as the river flow (Decharme et al., 2010).

Section 2 presents the LDAS-Monde system, i.e. (i) the $\mathrm{CO}_{2}$ responsive version of the ISBA LSM and the soil diffusion scheme, (ii) the CTRIP hydrological model and its coupling with ISBA, (iii) the atmospheric forcing used to drive the system, (iv) the equations of the SEKF, and (v) the assimilated remotely sensed observation dataset as well as the datasets used to assess the analysis impact. The latter is evaluated using agricultural statistics over France, river discharge, satellite-derived estimates of land transpiration and spatially gridded estimates of upscaled gross primary production from the FLUXNET network. Section 3 investigates 
and discusses the model sensitivity to the assimilated observations and provides a set of statistical diagnostics to assess and evaluate the analysis impact. Finally Sect. 4 provides perspective and future research directions.

\section{Materials and method}

\subsection{SURFEX offline data assimilation}

The SURFEX modelling system includes the ISBA land surface model (Noilhan and Mahfouf, 1996) to calculate the soil, vegetation, snow energy and water budgets and is coupled to the TRIP (Oki et al., 1998) river routing model in order to simulate the streamflow (SURFEX-CTRIP hereafter). SURFEX offline data assimilation implementation is used to set up a land data assimilation system (LDAS) over Europe and the Mediterranean basin (longitudes from $11.75^{\circ} \mathrm{W}$ to $62.50^{\circ} \mathrm{E}$, latitudes from 25.00 to $75.50^{\circ} \mathrm{N}$ ). It is defined as an offline sequential data assimilation system based on the ISBA LSM. It is capable of ingesting information from various satellite-derived observations to analyse and update SM and LAI simulated by ISBA. Analysis of ISBA prognostic variables then have an impact on the CTRIP variables (e.g. river discharge) through an interactive daily coupling (Voldoire et al., 2017). The system is driven by WFDEI observationbased atmospheric forcing dataset (Weedon et al., 2011, 2014). The main components of the LDAS (LSM, river routing system, analysis scheme and atmospheric forcing) are described in the following sections.

\subsubsection{ISBA land surface model}

ISBA models the basic land surface physics requiring only a small number of model parameters. The latter depend on the soil and vegetation types. This study uses the $\mathrm{CO}_{2}$ responsive version of ISBA, which is able to simulate the interaction between water and carbon cycles, photosynthesis, and its coupling to stomatal conductance (Calvet et al., 1998, 2004; Gibelin et al., 2006). The $\mathrm{CO}_{2}$-responsive version of ISBA has been developed to allow for different biomass reservoirs for the simulation of photosynthesis and the vegetation growth. The dynamic evolution of the vegetation biomass and LAI variables is driven by photosynthesis in response to atmospheric and climate conditions. Photosynthesis enables vegetation growth resulting from the $\mathrm{CO}_{2}$ uptake. During the growing phase, enhanced photosynthesis corresponds to a $\mathrm{CO}_{2}$ uptake, which results in vegetation growth from the LAI minimum threshold (prescribed as $1 \mathrm{~m}^{2} \mathrm{~m}^{-2}$ for coniferous forest or $0.3 \mathrm{~m}^{2} \mathrm{~m}^{-2}$ for other vegetation types). In contrast, a deficit of photosynthesis leads to higher mortality rates. The total evaporative flux represents the combination of the evaporation due to (i) plant transpiration, (ii) liquid water intercepted by leaves, (iii) liquid water contained in top soil layers, and (iv) the sublimation of the snow and soil ice. The $\mathrm{CO}_{2}$ uptake from photosynthe- sis is defined as the gross primary production (GPP) and the release of $\mathrm{CO}_{2}$ is called the ecosystem respiration (RECO). The net ecosystem $\mathrm{CO}_{2}$ exchange (NEE) measures the difference between these two quantities.

ISBA has an explicit snow scheme (with 12 layers), as detailed in Bonne and Etchevers (2001) and Decharme et al. (2016). The multi-layer soil diffusion scheme version (ISBA-Dif) is based on the mixed form of the Richards equation (Richards, 1931) and explicitly solves the one-dimensional Fourier law. Additionally, ISBA-Dif incorporates soil freezing processes developed by Boone et al. (2000) and Decharme et al. (2013). The total soil profile is vertically discretized and the temperature and the moisture of each layer are computed according to the textural and hydrological characteristics. The Brookes and Corey model (Brooks and Corey, 1966) determines the closed-form equations between the soil moisture and the soil hydrodynamic parameters, including the hydraulic conductivity and the soil matrix potential (Decharme et al., 2013). A discretization with 14 layers over $12 \mathrm{~m}$ depth is used. The lower boundary of each layer is $0.01,0.04,0.1,0.2,0.4,0.6,0.8,1,1.5$, 2, 3, 5, 8 and $12 \mathrm{~m}$ deep (see Fig. 1 of Decharme et al., 2011). The amounts of clay, sand and organic carbon present in the soil are determined by thermal and hydrodynamic soil properties (Decharme et al., 2016) and are taken from the Harmonised World Soil Database (HWSD, Wieder et al., 2014). As for hydrology, the infiltration, surface evaporation and total runoff are accounted for in the soil water balance. The discrepancy between the surface runoff and the throughfall rate is defined by the infiltration rate.

The throughfall rate is defined as the sum of rainfall that is not intercepted by the canopy, dripping from the canopy (interception reservoir), and snow melt water. Evaporation only affects the superficial layer, which represents the top $1 \mathrm{~cm}$ of soil. The soil evaporation is proportional to the relative humidity of the superficial layer. Transpiration water from the root zone (the region where the roots are asymptotically distributed) follows the equations in Jackson et al. (1996). More information on the root density profile is available in Canal et al. (2014). ISBA total runoff has two contributions: the surface runoff (the lateral subsurface flow in the topsoil) and a free drainage condition at the bottom layer. A basic TOPMODEL approach is used to compute the Dunne runoff (i.e. when no further soil moisture storage is available) and lateral subsurface flow from a sub-grid distribution of the topography. The Horton runoff (i.e. when rainfall has exceeded infiltration capacity) is estimated from the maximum soil infiltration capacity and a sub-grid exponential distribution of the rainfall intensity.

\subsubsection{CTRIP river routing}

The present CTRIP version consists of a global streamflow network at $0.5^{\circ}$ spatial resolution. The CTRIP model is driven by the three prognostic equations corresponding 
to the groundwater, the surface stream water and the seasonal floodplains. Streamflow velocity is computed using the Manning formula (Decharme et al., 2010). The floodplain reservoir fills when the river water level overtops the riverbank and empties again when the water level drops below this threshold (Decharme et al., 2012). Flooding impacts the ISBA soil hydrology through infiltration. It also influences the overlying atmosphere via free surface water evaporation and precipitation interception.

At last, the groundwater scheme (Vergnes and Decharme, 2012) is based on the two-dimensional groundwater flow equation for the piezometric head. Its coupling with ISBA permits the presence of a water table under the soil moisture column to be accounted for, allowing upward capillary fluxes into the soil (Vergnes et al., 2014). CTRIP is coupled to ISBA through OASIS-MCT (Voldoire et al., 2017). Once a day, ISBA provides CTRIP with updates on runoff, drainage, groundwater and floodplain recharges, and CTRIP returns to ISBA the water table depth or rise, floodplain fraction, and flood potential infiltration.

\subsubsection{Extended Kalman filter}

This section describes the analysis update of the extended Kalman filter while its application setup is described in Sect. 2.3.

The analysis update equation of the extended Kalman filter is as follows:

$\boldsymbol{x}_{\mathrm{a}}\left(t_{i}\right)=\boldsymbol{x}_{\mathrm{f}}\left(t_{i}\right)+\mathbf{K}_{i}\left(\boldsymbol{y}_{\mathrm{o}}\left(t_{i}\right)-h_{i}\left[\boldsymbol{x}_{\mathrm{f}}\right]\right)$.

The "a", "f" and "o" subscripts stand for analysis, forecast and observation, respectively. The term $\boldsymbol{x}$ denotes the control vector of dimension $N_{x}$, computed at time $t_{i}$, that represents the prognostic equations of the LSM $M$.

The term $\boldsymbol{y}_{\mathrm{o}}$ denotes the observation vector of dimension $N_{y}$. The Kalman gain matrix $\mathbf{K}_{i}$ is computed at time $t_{i}$ as follows:

$\mathbf{K}_{i}=\mathbf{B H}^{T}\left(\mathbf{H B H} \mathbf{H}^{T}+\mathbf{R}\right)^{-1}$.

A non-linear observation operator $h$ enables the extraction of the model counterpart of the observations:

$\boldsymbol{y}\left(t_{i}\right)=h(\boldsymbol{x})$.

$\mathbf{B}$ and $\mathbf{R}$ are error covariance matrices characterizing the forecast and observation vectors. The cross-correlated terms represent covariances. The operator $\mathbf{H}$ (and its transpose $\mathbf{H}^{T}$ ) from Eq. (2) is the Jacobian matrix: the linearized version of the observation operator (defined as $N_{y}$ rows and $N_{x}$ columns) that transforms the model states into the observation space. A numerical estimation of each Jacobian element is calculated by finite differences, by perturbing each component $x_{j}$ of the control vector $\boldsymbol{x}$ by a specific amount $\delta x_{j}$, resulting in a column of the matrix $\mathbf{H}$ for each integration $m$ :

$\mathbf{H}_{m j}=\frac{\partial y_{m}}{\partial x_{j}} \approx \frac{y_{m}\left(\boldsymbol{x}+\delta x_{j}\right)-y_{m}}{\delta x_{j}}$.
The control vector evolution from time $t_{i}$ to the end of the $24 \mathrm{~h}$ assimilation window $\left(t_{i+1}\right)$ is then controlled by the following equation:

$\boldsymbol{x}_{\mathrm{f}}\left(t_{i+1}\right)=M_{i}\left[\boldsymbol{x}_{\mathrm{a}}\left(t_{i}\right)\right]$.

In line with previous studies (e.g, Mahfouf et al., 2009; Albergel et al., 2010; Barbu et al., 2011, 2014; de Rosnay et al., 2013; Fairbairn et al., 2015, 2017) a fixed estimate of the background-error variances and zero covariances at the start of each cycle are used, leading to a SEKF. The initial state at the start of a $24 \mathrm{~h}$ assimilation window is analysed by assimilating the observations available over the previous $24 \mathrm{~h}$ assimilation window. This approach is similar to the "simplified 2-D-Var (two-dimensional variational data assimilation scheme)" proposed by Balsamo et al. (2004), but the increments are applied at the final timestep of the $24 \mathrm{~h}$ assimilation window. Draper et al. (2009) found that the SEKF could generate flow dependence from the $24 \mathrm{~h}$ assimilation window and that cycling the background-error covariance (as in the EKF) gave no additional benefit.

\subsection{Data and data processing}

\subsubsection{WFDEI observation-based atmospheric forcing dataset}

Atmospheric forcing from the WFDEI dataset (Weedon et al., 2011, 2014) is used to drive the LDAS. It spans the period 1979-2012 and contains 3-hourly time intervals of wind speed, atmospheric pressure, air temperature (averaged values are used), air humidity, incoming shortwave and longwave radiations, and solid and liquid precipitation. WFDEI originates from the ECMWF ERA-Interim reanalysis (Dee et al., 2011), interpolated to a spatial resolution of $0.5^{\circ}$, and is corrected with the CRU dataset (Climatic Research Unit, Harris et al., 2014) using a sequential elevation correction of surface meteorological variables plus monthly bias correction from gridded observations (e.g. precipitation data from the Global Precipitation Climatology Centre; GPCC). A more exhaustive description of the dataset is available in Schellekens et al. (2017).

\subsubsection{ESA CCI surface soil moisture}

This study makes use of a multi-sensor, long-term and global satellite-derived surface soil moisture dataset (Liu et al., 2011, 2012; Wagner et al., 2012; Dorigo et al., 2015, 2017) developed within The European Space Agency Water Cycle Multi-mission Observation Strategy (ESAWACMOS) project and Climate Change Initiative (CCI, http://www.esa-soilmoisture-cci.org). Several authors (e.g. Albergel et al., 2013a, b; Dorigo et al., 2015) have highlighted the quality and stability over time of the product. Despite some limitations, this dataset has shown potential for assessing model performance (Szczypta et al., 2014; 

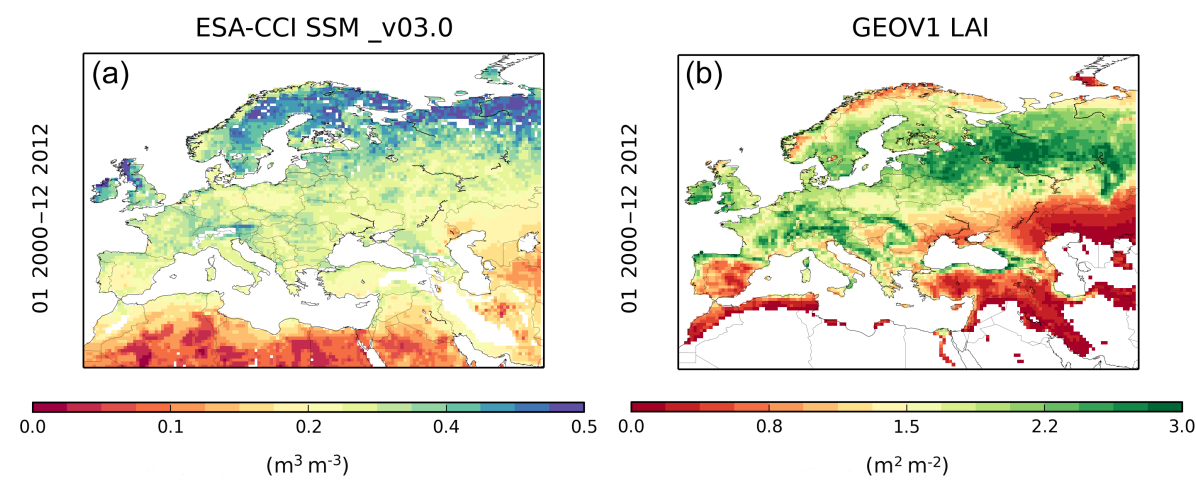

Figure 1. Averaged (a) surface soil moisture from the Climate Change Initiative project of ESA. (b) GEOV1 leaf area index from the Copernicus Global Land Service project (for pixels covered by more than $90 \%$ of vegetation) over 2000-2012.

van der Schrier et al., 2013), for investigating the connection between soil moisture and atmosphere-ocean oscillations (Bauer-Marschallinger et al., 2013) as well as vegetation dynamics (Barichivich et al.,2014; Muñoz et al., 2014). This study uses the ESA CCI SM COMBINED latest version of the product (v03.2) which merges SM observations from seven microwave radiometers (SMMR, SSM/I, TMI, ASMR-E, WindSat, AMSR2, SMOS) and four scatterometers (ERS-1 and 2 AMI and MetOp-A and B ASCAT) into a harmonious dataset covering the period November 1978 to December 2015. For a more comprehensive overview of the ESA CCI SM see Dorigo et al. (2015, 2017).

To assimilate SM data, it is important to rescale the observations such that they are consistent with the model climatology (Reichle and Koster, 2004; Drusch et al., 2005). The climatology of the SM dataset is defined by the specific mean value, variability and dynamical range. The ISBA model climatology for each grid point is dependent on the dynamical range, which is calculated from the wilting point and field capacity parameters (functions of soil texture types). It is necessary to transform the ESA CCI SSM product into model-equivalent SSM to address possible mis-specification of physiographic parameters, such as the wilting point and the field capacity. The linear rescaling approach described in Scipal et al. (2008) (using the first two moments of the cumulative distribution function, $\mathrm{CDF}$ ) has been used in this study; it is a linear rescaling that enables a correction of the differences in the mean and variance of the distribution. The first two moments, the intercept $a$ and the slope $b$, are as follows:

$a=\overline{\mathrm{SSM}}_{\mathrm{m}}-b \cdot \overline{\mathrm{SSM}}_{\mathrm{o}}$,

$b=\frac{\sigma_{\mathrm{m}}}{\sigma_{\mathrm{o}}}$

where $\overline{\mathrm{SSM}}_{\mathrm{m}}, \overline{\mathrm{SSM}}_{\mathrm{o}}, \sigma_{\mathrm{m}}$ and $\sigma_{\mathrm{o}}$ correspond to the model and observation means and standard deviations (SDs), respectively. Barbu et al. (2014) and Draper et al. (2011) discussed the importance of allowing for seasonal variability in the CDF matching. Parameters $a$ and $b$ vary spatially and were derived on a monthly basis by using a 3-month moving window over 2000-2012 after screening for the presence of ice and urban areas. The ESA CCI SSM observations are interpolated by an arithmetic average to the $0.5^{\circ}$ model grid points.

\subsubsection{GEOV1 leaf area index}

The GEOV1 LAI is produced by the European Copernicus Global Land Service project (http://land.copernicus.eu/ global/). The LAI observations are retrieved from the SPOTVGT and PROBA-V (from 1999 to present) satellite data according to the methodology discussed in Baret et al. (2013). Following Barbu et al. (2014), the $1 \mathrm{~km}$ resolution observations are interpolated by an arithmetic average to the $0.5^{\circ}$ model grid points, as long as $50 \%$ of the observation grid points are observed (half the maximum amount). LAI observations have a temporal frequency of 10 days. Both SSM and LAI observed datasets are illustrated in Fig. 1, which presents averaged values over 2000-2012. Figure 1 also illustrates the studied domain.

\subsubsection{Evaluation datasets and strategies}

A common diagnostic in data assimilation is to compute Eq. (1) differences between the assimilated observations and the model background, called the innovations, and Eq. (2) differences between the assimilated observations and the analysis, called the residuals (Barbu et al., 2011). Assuming that the system is working well, residuals have to be reduced compared to the innovations.

After evaluating innovations and residuals of SSM and LAI, analysis impact is assessed using Eq. (1) agricultural statistics over France, Eq. (2) observed river discharge over Europe, Eq. (3) satellite-derived estimates of terrestrial evapotranspiration from the Global Land Evaporation Amsterdam Model (GLEAM, Martens et al., 2017) and Eq. (4) spatially gridded estimates of upscaled GPP and evapotranspiration from the FLUXNET network (Jung et al., 2009, 2011). 
Smith et al. (2010a, b) demonstrated that crop simulations can be validated by agricultural statistics on a country scale. With a finer spatial scale over France, Calvet et al. (2012) benchmarked several configurations of the ISBA LSM using agricultural statistics (Agreste, 2016), namely the correlation between yield time series and above-ground biomass $\left(B_{\mathrm{ag}}\right)$ simulations. In ISBA, $B_{\mathrm{ag}}$ of herbaceous vegetation is made up of two components: the active biomass and the structural biomass. The former describes the photosynthetically active leaves and is linked to $B_{\text {ag }}$ by a nitrogen dilution allometric logarithmic law (Calvet and Soussana, 2001). Calvet et al. (2012), found that $B_{\text {ag }}$ simulated by the model is in agreement with the agricultural statistics, and therefore can be used to benchmark model and system development. Yearly statistical surveys over France are provided by the Agreste portal (http://agreste.agriculture.gouv.fr/). This has enabled a database of annual straw-cereal grain yield (GY) values to be established. The GY estimates are available according to administrative unit (département) and per crop type. Following Calvet et al. (2012), Canal et al. (2014) and Dewaele et al. (2017), the GY values for rainfed straw cereals over 45 départements are used, which include barley, oat, rye, triticale and wheat. Simulated and analysed annual maximum of $B_{\text {ag }}$ are compared to GY estimates following the methodology from Dewaele et al. (2017). Although SURFEX does not directly represent GY, it is assumed that the regional-scale simulations of above-ground biomass from a generic LSM can provide the inter-annual variability as a proxy for GY (Calvet et al., 2012; Canal et al., 2014).

Over 2000-2010, simulated and analysed river discharge is compared to gauging measurements from the Global Runoff Data Center (GRDC; http://grdc.sr.unh.edu/index. html) and the Banque Hydro (http://www.hydro.eaufrance. fr/) at a monthly time step. Data are chosen over the domain presented in Fig. 1 for sub-basins with large drainage areas $\left(10000 \mathrm{~km}^{2}\right.$ or greater) and with a long observation time series (4 years or more). It is common to express observed and simulated river discharge $(Q)$ data in cubic metres per second $\left(\mathrm{m}^{3} \mathrm{~s}^{-1}\right)$. However, given that the observed drainage areas may differ slightly from the simulated ones, scaled $Q$ values in millimetres per day $\left(\mathrm{mmd}^{-1}\right.$, the ratio of $Q$ to the drainage area) are used in this study. Stations with drainage areas differing by more than $15 \%$ from the simulated (analysed) ones are also discarded. This leads to 83 stations. Impact on $Q$ is evaluated using correlation, root mean square difference (RMSD) and the efficiency score (Eff) (Nash and Sutcliffe, 1970). Eff evaluates the model's ability to represent the monthly discharge dynamics and is given by the following:

$\mathrm{Eff}=1-\frac{\sum_{\mathrm{mt}=1}^{T}\left(Q_{s}^{\mathrm{mt}}-Q_{\mathrm{o}}^{\mathrm{mt}}\right)^{2}}{\sum_{\mathrm{mt}=1}^{T}\left(Q_{\mathrm{o}}^{\mathrm{mt}}-\bar{Q}_{\mathrm{o}}^{\mathrm{mt}}\right)^{2}}$,

where $Q_{\mathrm{s}}^{t}$ is the simulated river discharge (or analysed) at time $t$, and $Q_{\mathrm{o}}^{t}$ is observed river discharge at month mt. The
Eff can vary between $-\infty$ and 1 . A value of 1 corresponds to identical model predictions and observed data. A value of 0 implies that the model predictions have the same accuracy as the mean of the observed data. Negative values indicate that the observed mean is a more accurate predictor than the model simulation.

The GLEAM product uses a set of algorithms to estimate terrestrial evaporation and root-zone SM from satellite data (Miralles et al., 2011). It is a useful validation tool given that such quantities are difficult to measure directly on large scales. The global evaporation model in GLEAM is mainly driven by microwave remote sensing observations, while potential evaporation rates are constrained by satellite-derived SM data. It is a well-established dataset that has been widely used to study trends and spatial variability in the hydrological cycle (e.g. Jasechko et al., 2013; Greve et al., 2014; Miralles et al., 2014a; Zhang et al., 2016) and land-atmosphere feedbacks (e.g. Miralles et al., 2014b; Guillod et al., 2015). This study makes use of the latest version available, v3.0. It is a 35-year dataset spanning from 1980 to 2014 and is derived from a variety of sources, namely vegetation optical depth (VOD) and snow water equivalents (SWEs), satellite-derived $\mathrm{SM}$, reanalysis air temperature and radiation, and a multisource precipitation product (Martens et al., 2017). It is available at a spatial resolution of $0.25^{\circ}$. Martens et al. (2017) provide a full description of the dataset, including an extensive validation using measurements from 64 eddy-covariance towers worldwide.

The upscaled FLUXNET GPP and evapotranspiration were derived from the FLUXNET network using a model tree ensemble (FLUXNET-MTE hereafter) approach as described in Jung et al. (2009). It is a machine learning technique that can be trained to ascertain land-atmosphere fluxes, providing a way of benchmarking LSMs on large scales (Jung et al., 2009, 2010; Beer et al., 2010; Bonan et al., 2011; Jung et al., 2011; Slevin et al., 2017). The machine learning algorithm is trained using a combination of land cover data, observed meteorological data and remotely sensed vegetation properties (fraction of absorbed photosynthetic active radiation). The algorithm uses model tree ensembles to provide estimates of carbon fluxes at FLUXNET sites with available quality-filtered flux data, after which the trained model can be implemented globally using grids of the input data (Jung et al., 2009, 2011). It is limited to a $0.5^{\circ}$ spatial resolution and a monthly temporal resolution over a 20 -year period (1982-2011). It can be found in the Max Planck Institute for Biogeochemistry Data Portal (https://www.bgc-jena.mpg.de/ geodb/projects/Home.php).

\subsection{Experimental setup}

The LDAS used in this study is designed as follows: $\boldsymbol{x}$ is the eight-dimensional control vector including soil layers 2 to 8 (representing a depth from 1 to $100 \mathrm{~cm}$ ) and LAI propagated by the ISBA LSM. The term $y_{0}$ denotes the two-dimensional 
observation vector (SSM, LAI). The model counterparts of the observations are the second layer of soil of ISBA LSM ( $w_{2}$ between 1 and $4 \mathrm{~cm}$ ) and LAI for SSM and LAI observations, respectively. A comparison between ESA CCI SM and the two top ISBA soil layers suggests that the second layer of soil better represents the satellite-derived product (not shown). Also, the first layer of soil ( $1 \mathrm{~cm}$ depth) is discarded from the control vector as, over a $24 \mathrm{~h}$ window, it is more reactive to the atmospheric forcing than to a small initial perturbation (Draper et al., 2011; Barbu et al., 2014). This leads to the following expression of the Jacobians matrices:

$$
\mathbf{H}=\left(\begin{array}{cccc}
\frac{\partial \mathrm{SSM}^{t}}{\partial \mathrm{LAI}^{0}} & \frac{\partial \mathrm{SSM}^{t}}{\partial w_{2}^{0}} & \ldots & \frac{\partial \mathrm{SSM}^{t}}{\partial w_{8}^{0}} \\
\frac{\partial \mathrm{LAI}^{t}}{\partial \mathrm{LAI}^{0}} & \frac{\partial \mathrm{LAI}^{t}}{\partial w_{2}^{0}} & \ldots & \frac{\partial \mathrm{LAI}^{t}}{\partial w_{8}^{0}}
\end{array}\right) .
$$

Several studies (e.g. Draper et al., 2009; Rüdiger et al., 2010) have demonstrated that small perturbations $\left(10^{-3}\right.$ or less) lead to a good approximation of this linear behaviour, provided that computational round-off error is not significant. Following Draper et al. (2011) and Mahfouf et al. (2009), the soil moisture errors are assumed to be proportional to the dynamic range (the difference between the volumetric field capacity, $w_{\mathrm{fc}}$, and the wilting point, $\left.w_{\text {wilt }}\right)$, which is determined by the soil texture (Noilhan and Mahfouf, 1996); in this study the Jacobian perturbations were assigned values of $1 \times 10^{-4} \times\left(w_{\mathrm{fc}}-w_{\text {wilt }}\right)$. Following Rüdiger et al. (2010), the LAI perturbation was set to a fraction (0.001) of the LAI itself. In this configuration, for every $24 \mathrm{~h}$ analysis cycle, the LSM is run several times: first to get the model trajectory (forecast), then perturbing the initial conditions of the various control variables, allowing computation of the various terms of the Jacobians (Eq. 4).

For soil moisture in the second layer of soil, i.e. the model equivalent of the SSM observations, a mean volumetric SD error of $0.04 \mathrm{~m}^{3} \mathrm{~m}^{-3}$ is prescribed. A smaller mean volumetric SD error of $0.02 \mathrm{~m}^{3} \mathrm{~m}^{-3}$ is prescribed to the deeper layers, as suggested by several authors for RZSM (Mahfouf et al., 2009; Draper et al., 2011; Barbu et al., 2011, 2014). The observational SSM error is set to $0.05 \mathrm{~m}^{3} \mathrm{~m}^{-3}$ as in Barbu et al. (2014). This value is consistent with errors estimated from a range of remotely sensed soil moisture sources (e.g. de Jeu et al., 2008; Draper et al., 2011; Gruber et al., 2016). Soil moisture observational and background errors are also scaled by the model soil moisture range. The error SDs in the GEOV1 LAI and the modelled LAI (for modelled LAI values higher than $2 \mathrm{~m}^{2} \mathrm{~m}^{-2}$ ) are both assumed to be equal to $20 \%$ of the LAI values. In accordance with a study by Barbu et al. (2011), the modelled LAI values lower than $2 \mathrm{~m}^{2} \mathrm{~m}^{-2}$ are assigned a constant error of $0.4 \mathrm{~m}^{2} \mathrm{~m}^{-2}$.

SURFEX-CTRIP was spun up by cycling 20 times through the year 1990, and then a 10-year model run is allowed before considering both an open loop (a model run with no assimilation) and an analysis experiment over 2000-
2012. Diagnostic studies of the Jacobian values have usually been performed before, including new observation types (Chevallier and Mahfouf, 2001; Fillion and Mahfouf, 2003; Garand et al., 2001; Rudiger et al., 2010). That is why, following Rudiger et al. (2010), an analysis experiment without assimilating any observations has also been run over 2000-2012 to study the model sensitivity to the observations through the Jacobians. Table 1 summarizes the SURFEXCTRIP setup used in this study.

\section{Results}

\subsection{Consistency between the model and observations}

Consistency over time is crucial when assimilating long-term datasets. Several authors assessed the consistency of the ESA CCI soil moisture product with respect to re-analysis products (e.g. Loew et al., 2013; Albergel et al., 2013a, b) and in situ measurements (Dorigo et al., 2015, 2017). Lambin et al. (1999) found that the GEOV1 LAI dataset is also consistent over time and can be used, for example, for detection of change and for providing information on shifting trends or trajectories in land use and cover change. To verify the results from literature for the spatial and temporal domain considered in this study, a consistency evaluation both for SSM and LAI against the open-loop experiment has been performed. As observed SSM climatology is matched to the model climatology (see Sect. 2.2.2), consistency between observations and the model over time (2000-2012), is expressed as correlations on both absolute and anomaly time series. The latter is computed using monthly sliding windows as described in Albergel et al. (2009). Only significant correlation values (at $p$ value $<0.005$ ) are retained. For LAI, consistency is expressed both as correlations and RMSDs.

Median soil moisture correlation (anomaly correlation), of ESA CCI SSM with the SURFEX-CTRIP second layer of soil, $w_{2}$ between 1 and $4 \mathrm{~cm}$, is 0.65 (0.47) over 20002012. Year-to-year correlation (anomaly correlation), which can potentially be impacted by the prevailing conditions in the given years, ranges from $0.62(0.45)$ to $0.71(0.48)$. Although many different sensors are used over time and space to retrieve ESA CCI SSM, the product can be considered stable. Over the same period, correlation and RMSDs between GEOV1 LAI and SURFEX-CTRIP is 0.75 and $0.85 \mathrm{~m}^{2} \mathrm{~m}^{-2}$, correlations range from 0.72 in 2000 to 0.77 in 2012. RMSD values are relatively stable too with a minimum value of $0.76 \mathrm{~m}^{2} \mathrm{~m}^{-2}$ in 2002 and a maximum of $0.91 \mathrm{~m}^{2} \mathrm{~m}^{-2}$ in 2007. Figure 2 (blue line) illustrates seasonal RMSDs (Fig. 2a) and correlations (Fig. 2b) between LAI from the open loop and the GEOV1 LAI estimates over 2000-2012. From Fig. 2a, a strong seasonal dependency of RMSD is noticeable with values close to $1 \mathrm{~m}^{2} \mathrm{~m}^{-2}$ from June to October. During these months correlation is better, with values between 0.75 and 0.85 . Too-large RMSD values ob- 

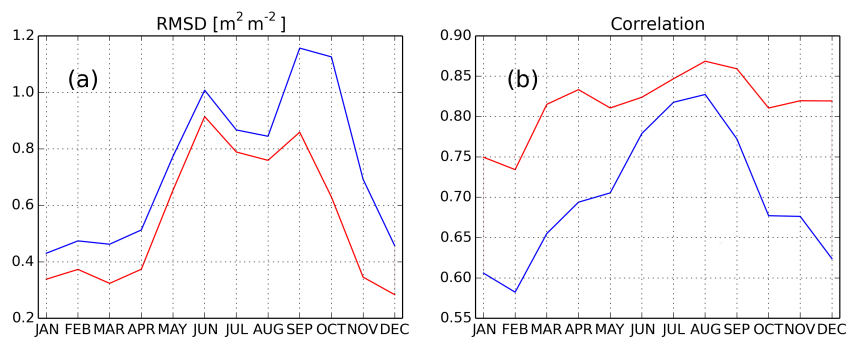

-Open loop — Analysis

Figure 2. Seasonal (a) RMSD and (b) correlation values between leaf area index (LAI) from the open-loop, analysis and GEOV1 LAI estimates from the Copernicus Global Land Service project over 2000-2012.

served in winter time are not desirable since the vegetation is supposed to be dormant.

Overall both ESA CCI SSM and GEOV1 LAI were found to be stable over time with respect to SURFEX-CTRIP, as illustrated in Fig. 3 for 2000, 2006 and 2012. Figure 3a-c illustrate correlations between ESA CCI SSM and SURFEXCTRIP $\left(w_{2}\right)$. While in 2000 not all of Europe is covered, it is the case from 2003 onwards. Low correlation values are found in desert areas (over the Sahara), high elevation (e.g. over the Alps) and at high latitudes, whereas high correlation values are obtained over, for example, the Iberian Peninsula, France and Turkey. Figure $3 \mathrm{~d}-\mathrm{f}$ present the correlations and RMSD values for GEOV1 LAI with SURFEX-CTRIP, respectively, only for vegetated grid points (> $90 \%)$. Generally, LAI at high elevation is not represented well (low correlations and high RMSD) as well as in the northeastern part of the domain, which is mainly covered by broad-leaved trees. Conversely, the southern part of the domain presents high levels of correlations and low RMSD values.

\subsection{Model sensitivity to observations}

The Jacobians, H (Eq. 4), are dependent on the model physics. The examination of the Jacobians provides useful insight into explaining the data assimilation system performances (Barbu et al., 2011; Fairbairn et al., 2017). Median values over 2000-2012 are presented in Table 2.

The model equivalent of SSM is the second layer of soil ( $w_{2}$ between 1 and $4 \mathrm{~cm}$ depth). It is then expected that the sensitivity of SSM to changes in soil moisture of that layer is higher than those of the other layers of soil. Sensitivity of LAI to changes in soil moisture (Table 2, bottom rows) suggests that control variables related to soil moisture will also be impacted by the assimilation of LAI. The model sensitivity to SSM decreases with depth, as presented in Table 2 revealing that the assimilation of SSM will be more effective in modifying soil moisture from the first layers. Over Europe, median values of $\mathbf{H}$ with respect to SSM observations (Table 2 top rows) range from 0.1719 to 0.0001 for 

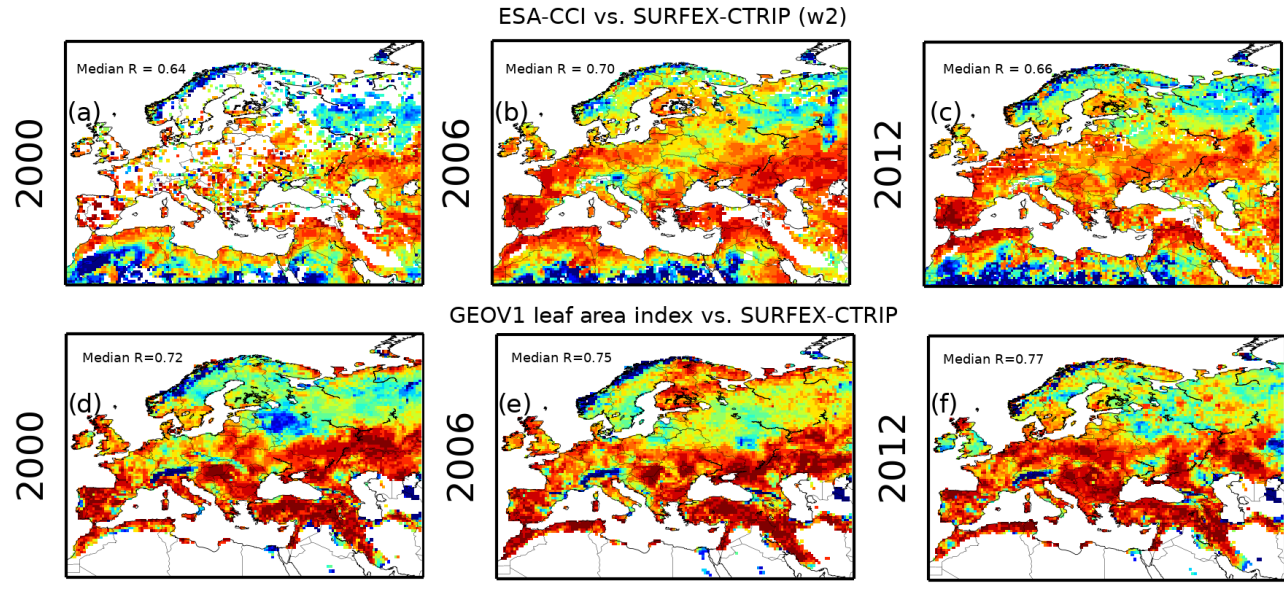

GEOV1 leaf area index vs. SURFEX-CTRIP
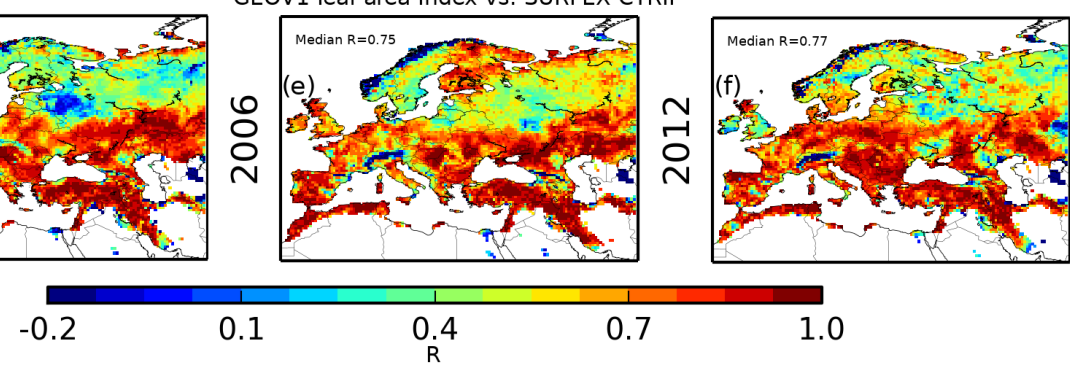

GEOV1 leaf area index vs. SURFEX-CTRIP

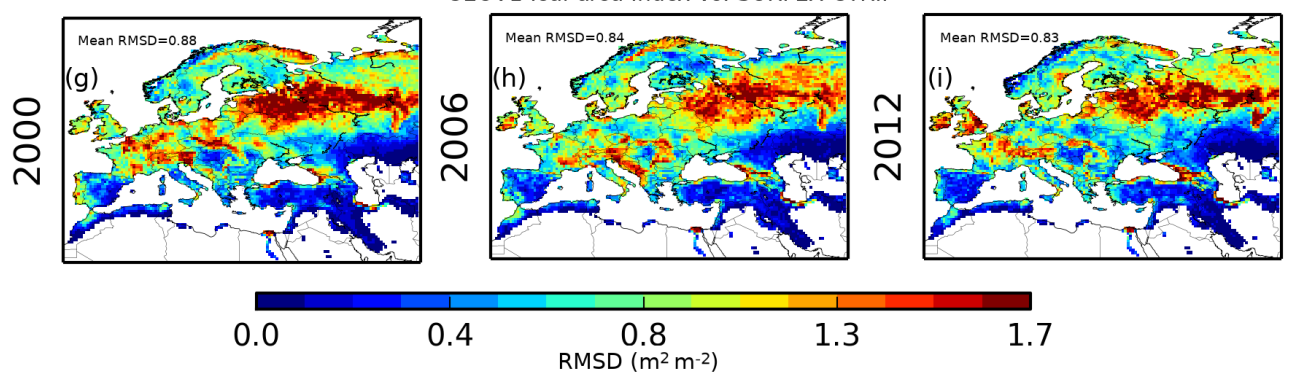

Figure 3. Top row, yearly averaged correlations between satellite-derived surface soil moisture from the Climate Change Initiative project from ESA and the second layer of soil of SURFEX-CTRIP ( $w_{2}: 1-4 \mathrm{~cm}$ depth) for (a) 2000, (b) 2006 and (c) 2012. (d-f) Yearly averaged correlation between the GEOV1 leaf area index from the Copernicus Global Land Service project and SURFEX-CTRIP for 2000, 2006 and 2012, respectively. (g-i) same as (d-f) for RMSD.

Table 2. Median Jacobian values for the eight control variables considered in this study over the whole spatial domain for $2000-2012$.

\begin{tabular}{|c|c|c|c|c|c|c|c|c|}
\hline 2000-2012 & $\frac{\partial \mathrm{SSM}^{t}}{\partial \mathrm{LAI}^{0}}$ & $\begin{array}{l}\frac{\partial \mathrm{SSM}^{t}}{\partial w_{2}{ }^{0}} \\
1-4 \mathrm{~cm}\end{array}$ & $\begin{array}{c}\frac{\partial \mathrm{SSM}^{t}}{\partial w_{3}{ }^{0}} \\
4-10 \mathrm{~cm}\end{array}$ & $\begin{array}{c}\frac{\partial \mathrm{SSM}^{t}}{\partial w_{4}{ }^{0}} \\
10-20 \mathrm{~cm}\end{array}$ & $\begin{array}{c}\frac{\partial \mathrm{SSM}^{t}}{\partial w_{5}{ }^{0}} \\
20-40 \mathrm{~cm}\end{array}$ & $\begin{array}{c}\frac{\partial \mathrm{SSM}^{t}}{\partial w_{6}{ }^{0}} \\
40-60 \mathrm{~cm}\end{array}$ & $\begin{array}{c}\frac{\partial \mathrm{SSM}^{t}}{\partial w_{7}^{0}} \\
60-80 \mathrm{~cm}\end{array}$ & $\begin{array}{c}\frac{\partial \mathrm{SSM}^{t}}{\partial w_{8}{ }^{0}} \\
80-100 \mathrm{~cm}\end{array}$ \\
\hline \multirow[t]{2}{*}{ Median } & -0.0010 & 0.1719 & 0.1543 & 0.0694 & 0.0275 & 0.0043 & 0.0006 & 0.0001 \\
\hline & $\frac{\partial \mathrm{LAI}^{t}}{\partial \mathrm{LAI}^{0}}$ & $\begin{array}{l}\frac{\partial \mathrm{LAI}^{t}}{\partial w_{2}{ }^{0}} \\
1-4 \mathrm{~cm}\end{array}$ & $\begin{array}{c}\frac{\partial \mathrm{LAI}^{t}}{\partial w_{3}{ }^{0}} \\
4-10 \mathrm{~cm}\end{array}$ & $\begin{array}{c}\frac{\partial \mathrm{LAI}^{t}}{\partial w_{4}{ }^{0}} \\
10-20 \mathrm{~cm}\end{array}$ & $\begin{array}{c}\frac{\partial \text { LAI }^{t}}{\partial w_{5}{ }^{0}} \\
20-40 \mathrm{~cm}\end{array}$ & $\begin{array}{c}\frac{\partial \text { LAI }^{t}}{\partial w_{6}{ }^{0}} \\
40-60 \mathrm{~cm}\end{array}$ & $\begin{array}{c}\frac{\partial \text { LAI }^{t}}{\partial w_{7}{ }^{0}} \\
60-80 \mathrm{~cm}\end{array}$ & $\begin{array}{c}\frac{\partial \mathrm{LAI}^{t}}{\partial w_{8}{ }^{0}} \\
80-100 \mathrm{~cm}\end{array}$ \\
\hline Median & 0.2220 & 0.0006 & 0.0015 & 0.0032 & 0.0068 & 0.0038 & 0.0011 & 0.0006 \\
\hline
\end{tabular}

layers $w_{2}$ to $w_{8}$, respectively, and is -0.0001 for LAI. The negative value of $\frac{\partial \mathrm{SSM}^{t}}{\partial \mathrm{LAI}^{0}}$ also indicates that a positive increment of LAI will generally lead to a decrease of SSM $\left(w_{2}\right)$. The depth impact is also illustrated in Fig. 4 which represents histograms of $\mathbf{H}$ over Europe for three control variables $\left(w_{2}\right.$ in red, $w_{4}$ in cyan and $w_{8}$ in blue) with respect to a change in SSM for 6 months (January, March, June, August, October, December) over 2000-2012 (Fig. 4a-f). Additionally Fig. 4 depicts a seasonal dependency. For instance, the histogram representing $\mathbf{H}$ of control variable $w_{2}$ (Fig. 4a) presents mainly three types, Eq. (1) values close or equal to
0 (type_A), Eq. (2) values between 0.2 and 0.8 (type_B), and Eq. (3) close to 1 (type_C). The values of type_C correspond to the situation in which the model dynamic is close to the identity, i.e. the perturbation of the initial state is almost unchanged by the end of the assimilation window $(24 \mathrm{~h})$. For values of type_B, the model dynamic is strongly dissipative and therefore the final offset is only a fraction of the initial perturbation. Distributions of types A, B and C vary in time; for January they are 75,14 and $11 \%$, for June they are 36 , 44 and $20 \%$, and for October they are 48, 30 and $22 \%$, respectively. It suggests a higher sensitivity of the first layers 

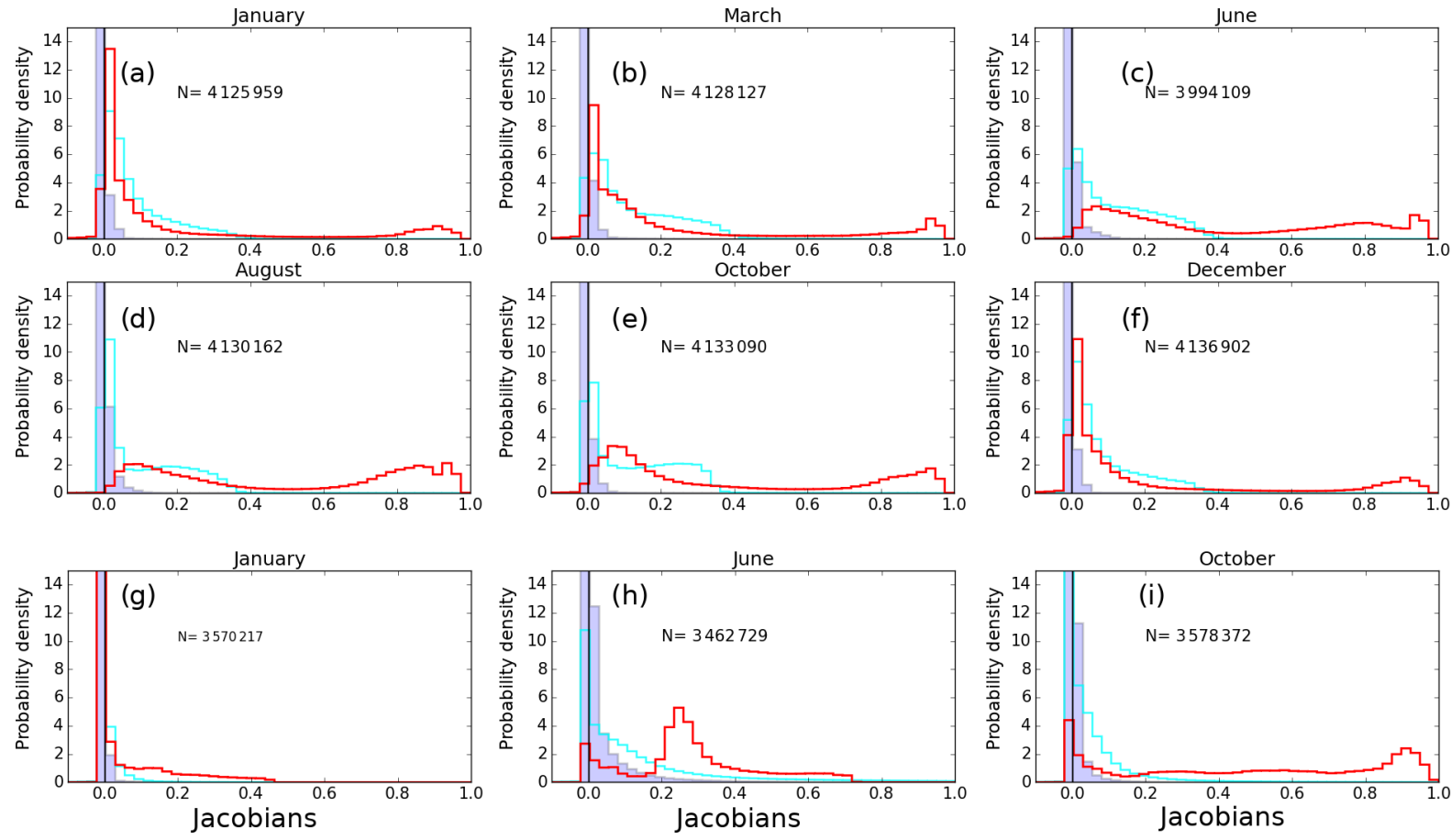

Figure 4. Jacobian value distribution: (a-f), $\frac{\partial \mathrm{SSM}^{t}}{\partial w_{2}{ }^{0}}$ (red line), $\frac{\partial \mathrm{SSM}^{t}}{\partial w_{4}{ }^{0}}$ (cyan line) and $\frac{\partial \mathrm{SSM}^{t}}{\partial w_{8}{ }^{0}}$ (blue line) for all months of January, March, June, August, October and December over 2000-2012, (g-i), $\frac{\partial \mathrm{LAI}^{t}}{\partial \mathrm{LAI}^{0}}$ (red line), $\frac{\partial \mathrm{LAI}}{\partial w_{4}{ }^{0}}$ (cyan line) and $\frac{\partial \mathrm{LAI}}{\partial w_{8}{ }^{0}}$ (blue line) for all months of January, June and October over 2000-2012. A black solid line represents a value of 0 .

of soil to a change in SSM, particularly during late summer and autumn rather than during winter months. While a similar behaviour is observed up to the fourth layer of soil, the deepest layers of soil (e.g. $w_{8}$, blue line) do not show any seasonal dependency, and very small sensitivity with mainly Jacobian values of type A.

The same typology can apply to $\mathbf{H}$ values $\frac{\partial \mathrm{LAI}}{\partial \mathrm{LAI}^{t}}$ (Fig. $4 \mathrm{~g}-$ i), with an even stronger seasonal dependency. For all months of January, distributions are 81,18 and $1 \%$, while they are 22,77 and $1 \%$ for all months of June and 27, 45 and $28 \%$ for all months of October for types A, B and C, respectively. Assimilation of LAI will be more effective in modifying LAI from late spring to autumn. Finally, the assimilation of LAI will be more effective in modifying soil moisture from layers 4 to 6 (Table 2).

\subsection{Impact of the analysis on control variables}

Control variables are directly impacted by the assimilation of LAI and SSM. Figure 5 illustrates averaged analysis increments for the period 2000-2012 for LAI and soil moisture in $w_{2}$ (between 1 and $4 \mathrm{~cm}$ ), $w_{4}$ (between 10 and $20 \mathrm{~cm}$ ) and $w_{6}$ (between 40 and $60 \mathrm{~cm}$ ) for all months of February, May, August and October. Red (blue) colours indicate that the analysis removes (adds) LAI and soil moisture. At the beginning of the year vegetation is not very active, but on the very western part of the domain the analysis tends to add LAI over the United Kingdom and northwestern parts of France and it reduces LAI over the Iberian Peninsula. At the beginning of the year soil moisture is only slightly affected by the analysis. Later in spring and summer the analysis is more efficient: it removes LAI over a large part of Europe, reducing the bias observed between open loop and observations. It mainly adds water in $w_{2}$ and remove water from layers $w_{4}$ to $w_{6}$. The seasonally marked impact of the analysis is consistent with the above description of the Jacobians behaviour. Analysis increments are also presented in Fig. 6 for the entire period 2000-2012. Generally, the analysis tends to remove LAI and add water in $w_{2}$ but dries layers where the roots are mainly located (from $w_{4}$ to $w_{6}$ ). Its effect is, however, less pronounced at greater depths.

Figure 7 shows the averaged analysis impact on LAI for all months of January, April, July and October over 2000-2012 expressed in RMSD in the following way: GEOV1 LAI vs. open loop and GEOV1 LAI vs. analysis. Only points where observed LAI is available (and assimilated) are retained. As this impact assessment is conducted against the observations that were assimilated, improvements from the analysis are expected and show that the LDAS is working well. From Fig. 7, this is mostly the case (e.g. in October). As indicated in Sect. 3.2, the analysis is most efficient during late summer and autumn. The geographical patterns highlighted in Sect. 3.1 are also observed with a clear improvement, e.g. in 


\section{LAl increments}
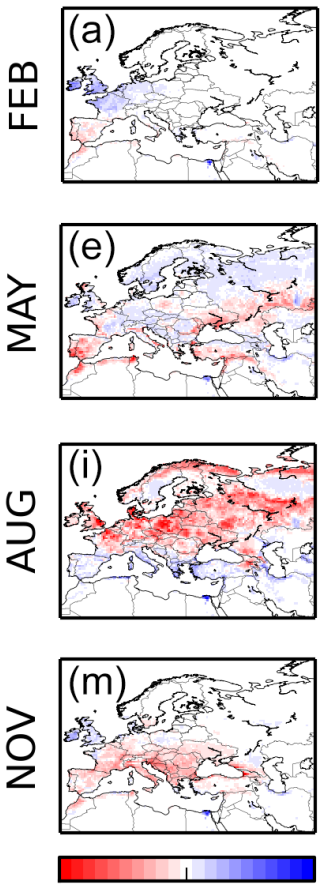

$-5 e-02 \quad 0 e+00 \quad 5 e-02$
WG2 increments
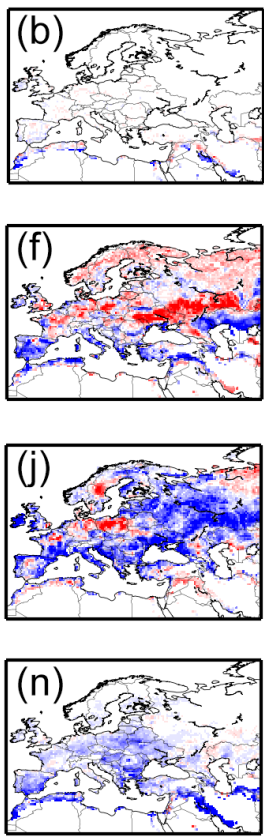

WG4 increments
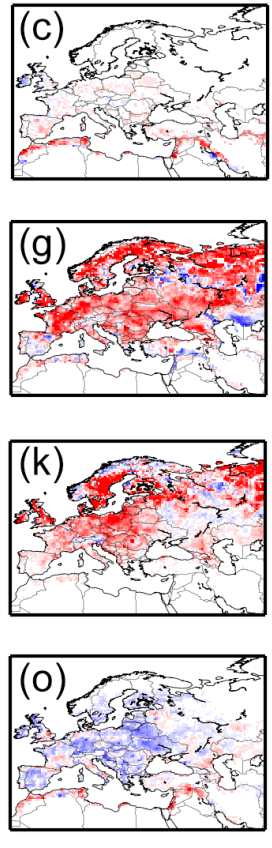

$-5 e-040 e+00 \quad 5 e-04$ $\left(\mathrm{m}^{3} \mathrm{~m}^{-3}\right)$

\section{WG6 increments}
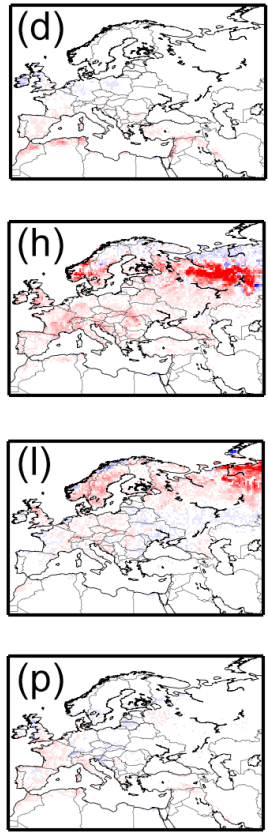

Figure 5. Rows from top to bottom represent averaged analysis increments for all months of February, May, August and November over 2000-2012. From left to right, four control variables are illustrated: leaf area index and soil moisture in the second $\left(w_{2}, 1-4 \mathrm{~cm}\right)$, fourth $\left(w_{4}\right.$, $10-20 \mathrm{~cm})$ and sixth $\left(w_{6}, 40-60 \mathrm{~cm}\right)$ layer of soil, respectively.

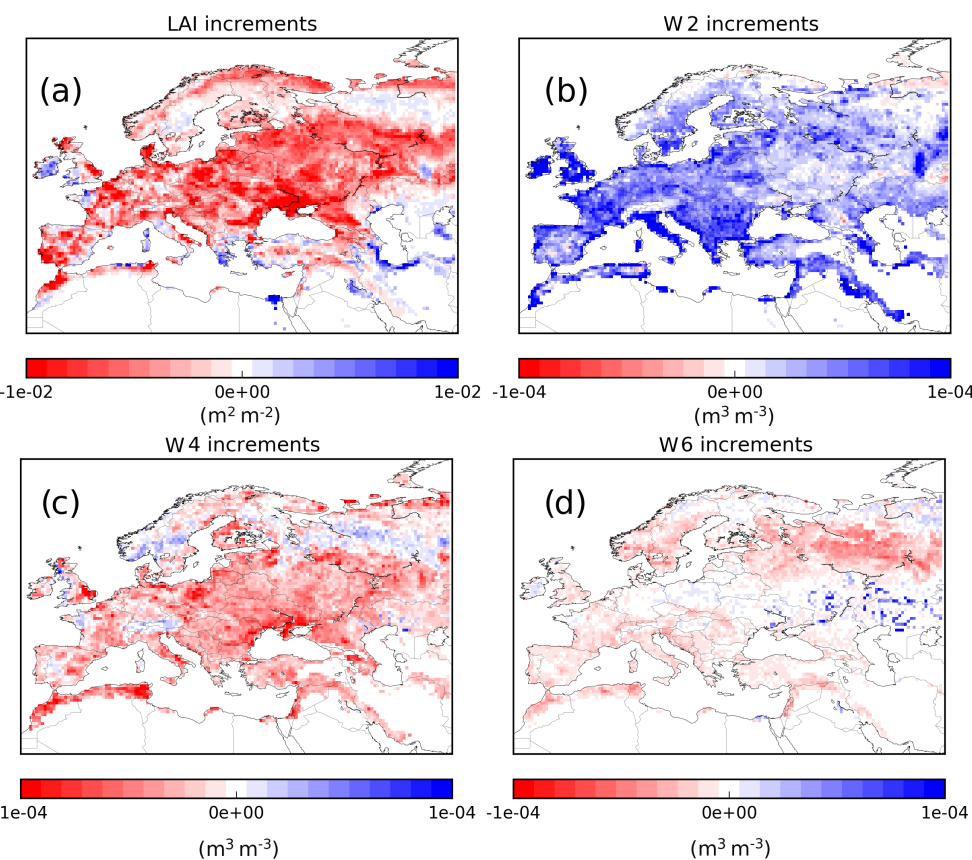

Figure 6. Averaged analysis increments for the whole period 2000-2012. Four control variables are illustrated: (a) leaf area index and soil moisture in (a) the second $\left(w_{2}, 1-4 \mathrm{~cm}\right),(\mathbf{b})$ fourth $\left(w_{4}, 10-20 \mathrm{~cm}\right)$ and $(\mathbf{c})$ sixth $\left(w_{6}, 40-60 \mathrm{~cm}\right)$ layer of soil. 
GEOV1 leaf area index vs. SURFEX-CTRIP
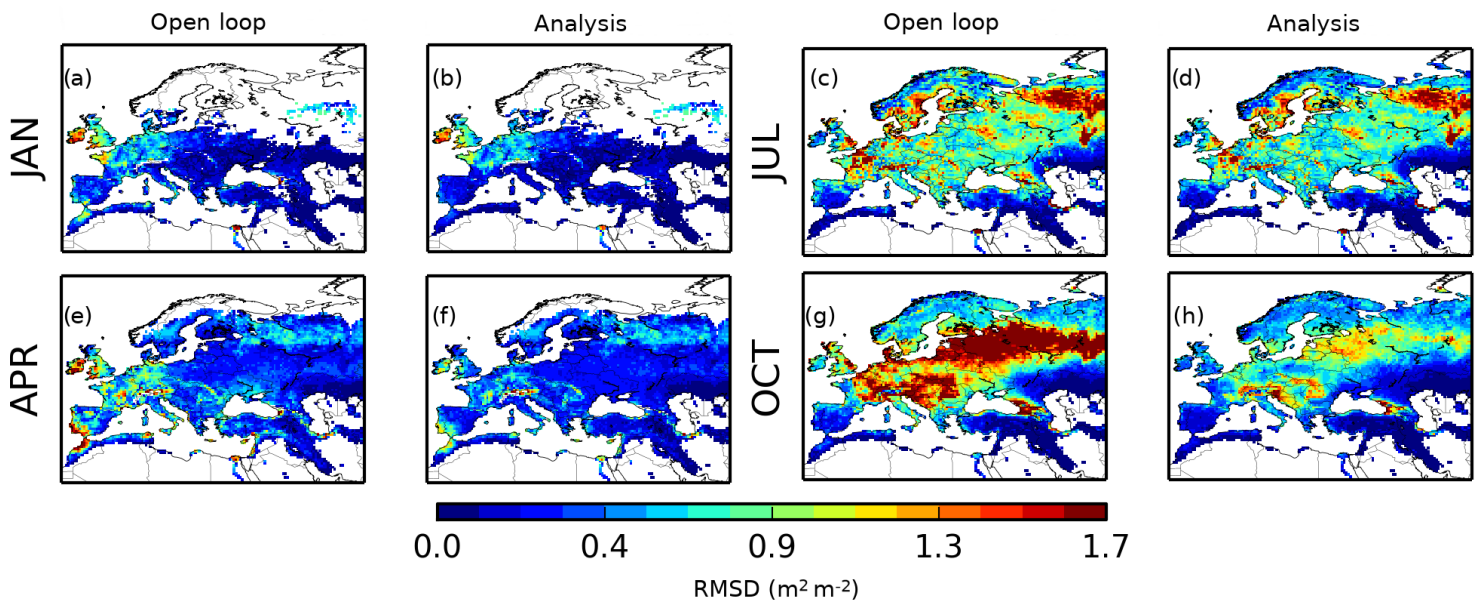

Figure 7. RMSD maps between leaf area index from the open loop (analysis) and that from the Copernicus Global Land Service project GEOV1 index for (a, b) January, (e, f) April, (c, d) July and (g, h) October over 2000-2012.
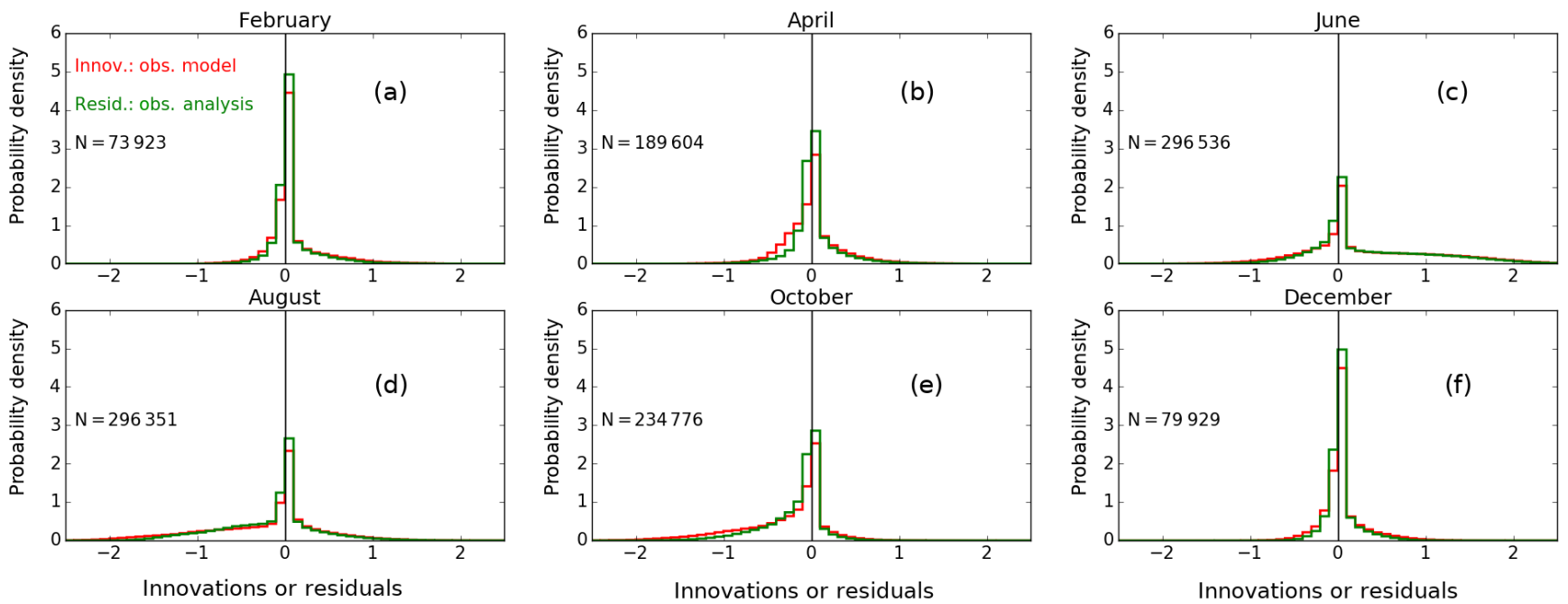

Figure 8. Probability density function of innovation (observations-open loop in red) and residuals (observations-analysis, in green) for leaf area index for (a) February, (b) April, (c) June, (d) August, (e) October and (f) December over 2000-2012. Sampling ( $N$ ) is reported on each panel.

the northeastern part of the domain. Analysis improvement with respect to the observations is also visible in Fig. 7.

Figure 8 illustrates histograms of innovations (in red) and residuals (in green) of LAI for all months of February, April, June, August, October and December over 2000-2012. As expected, the distribution of residuals is more centred on 0 than the distribution of the innovations. A seasonal pattern can be observed: during the growing phase (and up to June), both innovations and residuals present a right tail indicating that the model (and the analysis to a lesser extent) tends to underestimate LAI. In this period, similarities between innovations and residuals suggest that the analysis is not very efficient. At the end of summer and in autumn, distributions present a left-tail distribution; LAI is overestimated but this time the analysis is more efficient. Distributions of SSM residuals are even more centred on zero than those of innovations with no seasonal dependency and smaller differences (not shown). The common CDF-matching technique applied to SSM to remove systematic errors is responsible for this smaller impact, as the LDAS can only correct SSM short-term variability. Contrary to SSM, the LAI mismatch between the open loop and the GEOV1 estimates concerns both magnitude and timing (see for example Fig. 6 in Barbu et al., 2014).

Figure 9 presents averaged differences over 2000-2012 between the open loop and the analysis for other land sur- 

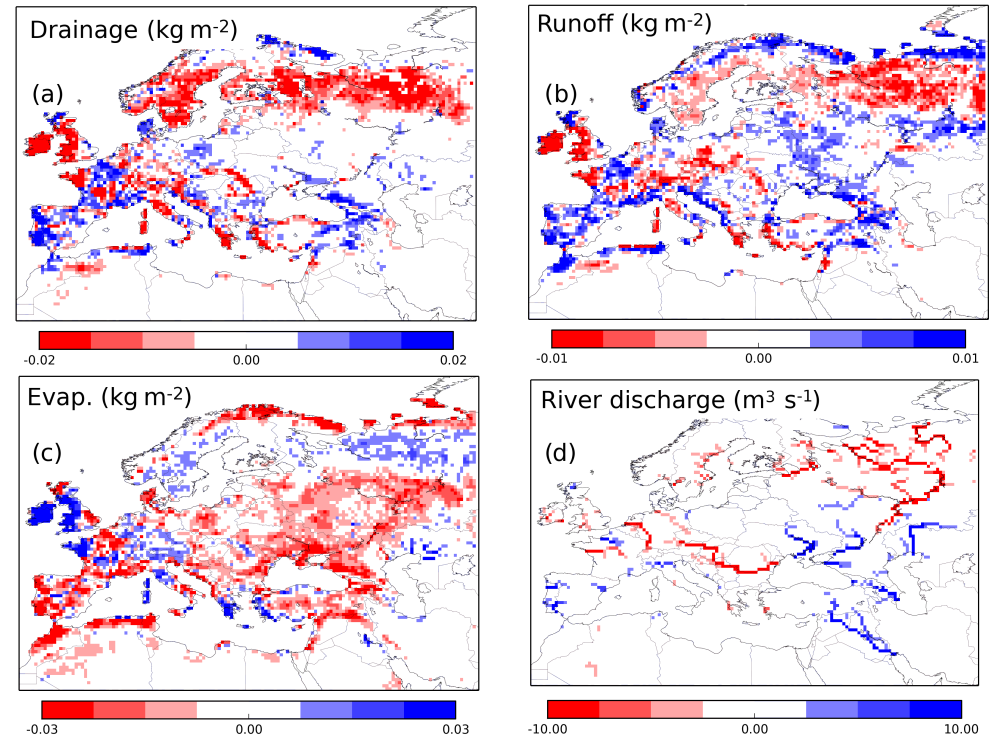

Figure 9. Averaged analysis impact on land surface variables that are indirectly affected over the period 2000-2012: (a) drainage, (b) runoff, (c) evapotranspiration and (d) river discharge.

face variables that are indirectly impacted by the assimilation, namely daily cumulated soil drainage flux, supersaturation runoff, evapotranspiration and daily mean river discharge. Although the analysis impact is relatively weak on those variables (e.g. $\sim 1 \%$ on the river discharge represented over the Danube), geographical patterns are observed. Areas where positive analysis increments were found for LAI (Fig. 5) tend to correspond to a decrease in drainage and runoff (in red in Fig. 9) while evapotranspiration increases (in blue Fig. 9). Changes in these indirectly impacted land surface variables are in agreement with the analysis increment maps (Fig. 6).

\subsection{Evaluation of analysis impact}

First, the evaluation of the analysis impact is effectuated over France using straw cereal GY values from the Agreste French agricultural statistics portal. Only the département administrative units corresponding to a high proportion of straw cereals are considered. Yearly maximal above-ground biomass $\left(B_{\mathrm{ag}}\right)$ values from the open loop (i.e model) and analysis are compared to GY over 2000-2010. Yearly-scaled anomalies from the mean and the SD for observations, open loop and analysis are used for 45 sites over France as in Dewaele et al. (2017). Figure 10a and 10b present correlations and RMSD values, respectively, and Fig. 10c shows time series for one site illustrating the inter-annual variability. After assimilation of SSM and LAI, correlation as well as RMSD between $B_{\text {ag }}$ and GY is clearly improved for 43 and 41 sites, respectively, out of 45 sites showing the added value of the analysis compared to the open loop. Figure 10c presents $B_{\text {ag }}$ from the open loop (black dashed line) and analysis (black
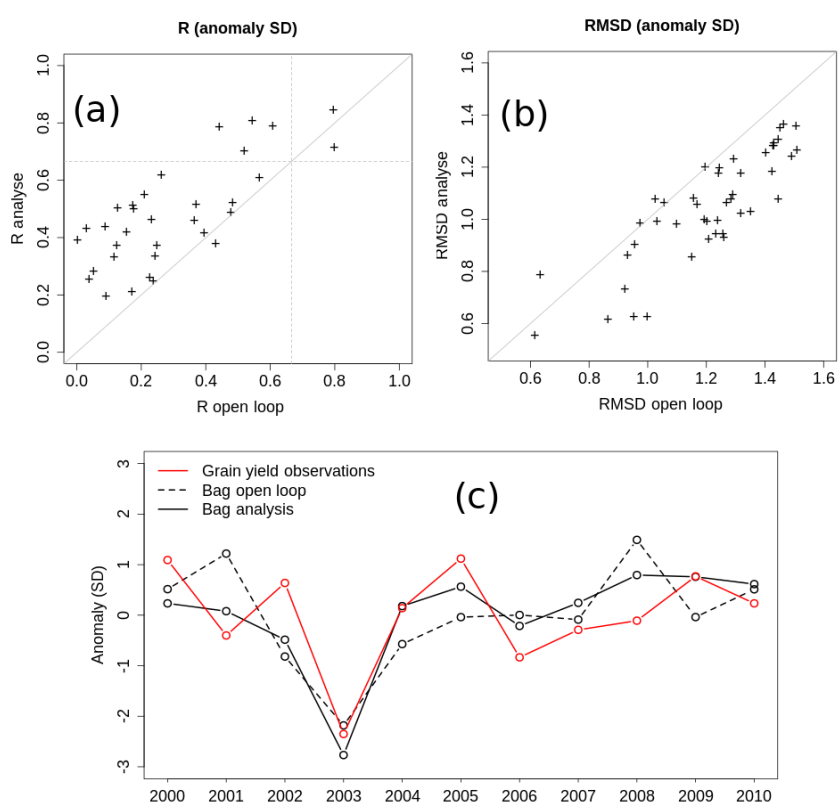

Figure 10. (a) Correlation values for the above-ground biomass from the open loop with grain yield estimates from Agreste French agricultural statistics portal (http://agreste.agriculture.gouv.fr) over 45 sites in France, plotted against correlations between the same quantities but above-ground biomass from the analysis; (b) same as (a) for RMSD values; (c) scaled anomaly time series of aboveground biomass from the open loop (black dashed line), analysis (black solid line) and grain yield observations (red solid) for one site in Allier, France $\left(46.09^{\circ} \mathrm{N}, 3.21^{\circ} \mathrm{E}\right)$. 


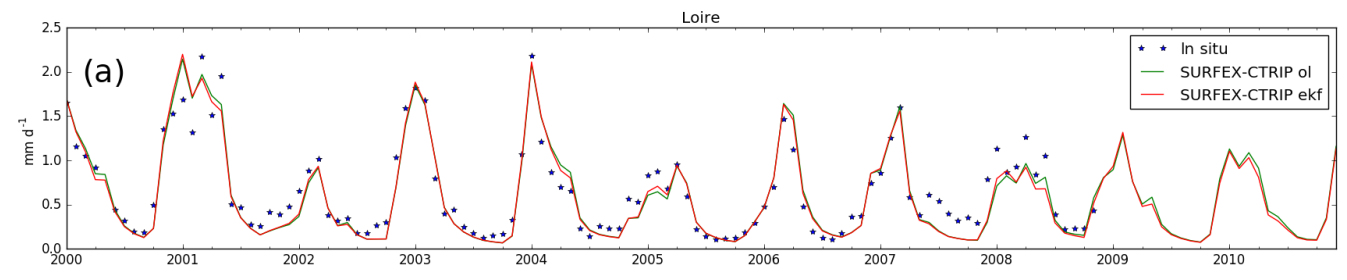

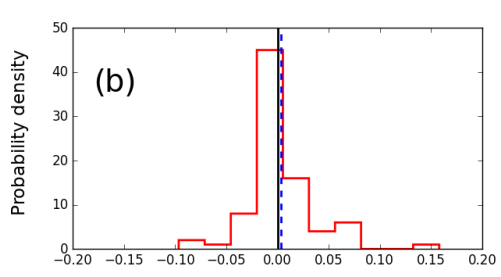

Eff. open loop - analysis

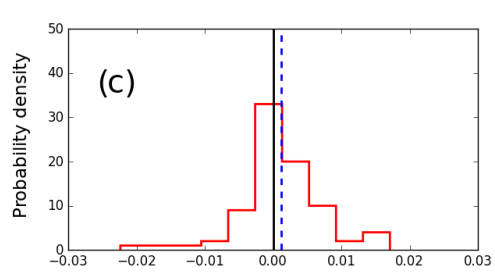

R. open loop - analysis

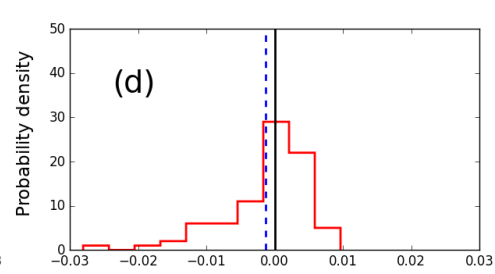

RMSD open loop - analysis

Figure 11. (a) Hydrograph for the Loire River in France $\left(47.25^{\circ} \mathrm{N}, 1.52^{\circ} \mathrm{W}\right)$ representing scaled river discharge $Q$ (using either observed or simulated drainage areas), in situ data (blues dots), open loop (green solid line) and analysis (red solid line); (b-d) histograms of efficiency, correlations and RMSD differences between $Q$ from the open loop and the analysis compared to the observations for the 83 stations retained (see Sect. 2.2.3 on evaluation strategy).

solid line) as well as observed GY (red solid line) scaled anomaly time series for one site in Allier, France $\left(46.09^{\circ} \mathrm{N}\right.$, $3.21^{\circ} \mathrm{E}$ ). Correlations and RMSD for open loop and analysis experiments are 0.45 and $0.99,0.78$ and 0.63 , respectively.

Over 2000-2010, 48 of 83 gauge stations present Eff values greater than 0 , and 22 gauge stations report Eff greater than 0.5 . As suggested in the previous section, the analysis impact on river discharge is rather small. If the analysis generally leads to an improvement in river discharge representation, only 8 stations present an Eff increase greater than to 0.05 ( 3 stations report a decrease greater than 0.05 ). Eff, $R$ and RMSD histograms of differences are presented in Fig. 11b, c and d along with a hydro-graph (Fig. 11a) for the Loire River in France $\left(47.25^{\circ} \mathrm{N}, 1.52^{\circ} \mathrm{W}\right)$. Although the assimilation impact is relatively small, evaluation results suggest that they are neutral to positive. Analysis impact on other CTRIP variables (e.g. floodplain fraction and storage, groundwater height) is rather neutral.

Evapotranspiration from both the open loop and the analysis are compared to monthly values of GLEAM satellitederived estimates over 2000-2012 for vegetated grid points $(>90 \%)$. As for the river discharge, the assimilation impact on evapotranspiration is small. However, the comparison with the GLEAM satellite-derived estimates is rather positive, as illustrated in Fig. 12, which represents evapotranspiration from the open loop (Fig. 12a), GLEAM estimates (Fig. 12b), the analysis (Fig. 12c) and their differences (Fig. 12d). Open-loop simulation of evapotranspiration tends to over-estimate the GLEAM product over most of Europe, particularly over France, the Iberian Peninsula and northern Africa. Analysis is able to reduce this bias (Fig. 12d). Figure 14 shows maps of RMSD (Fig. 14a) and correlation (Fig. 14b) differences: scores between the analysis and the GLEAM estimates minus scores between the open loop and the GLEAM estimates. Most of the pixels present negative values for differences in RMSD (76\% Fig. 14a) indicating that for those pixels RMSDs from the analysis are smaller than those from the open loop. Most of the pixels present positive values for differences in correlations $(80 \%$ Fig. 14b indicating that for those pixels correlations from the analysis are higher than those from the open loop. It shows the added value of the analysis when compared to an open loop. Evapotranspiration from the open loop and analysis has also been evaluated using FLUXNET-MTE estimates of evapotranspiration (2000-2011). Results are illustrated by Figs. 12e-h and $14 \mathrm{e}, \mathrm{f}$. They are similar to those obtained using GLEAM estimates: over the whole domain most of the pixels present negative values for differences in RMSD (70\%), and most of the pixels present positive values for differences in correlation $(79 \%)$.

As for evapotranspiration, GPP from both the open loop and the analysis are compared to monthly GPP estimates from FLUXNET-MTE dataset. Figure 12 illustrates averaged carbon uptake by GPP over land for 2000-2011 from the open loop (Fig. 13a), FLUXNET-MTE (Fig. 13b) and the analysis (Fig. 13c) as well as differences between the analysis and the model (Fig. 13d). Also, Fig. 14c and d show RMSD and correlation differences between the open loop or the analysis and FLUXNET-MTE dataset (analysis minus open loop). Finally Fig. 15 presents seasonal scores over the same period (Fig. 15a: RMSD values; Fig. 15b: correlation values). Compared to the FLUXNET-MTE estimates, the open loop tends to underestimate GPP over the Scandinavian countries, the northwestern part of France, the UK and Ireland, and north of the Caspian Sea, while an overestimation is visible over most of the Iberian peninsula, eastern Europe and the north-eastern part of the domain (Fig. 14a and b). From Figs. 14d, e and 15 one may notice that after 

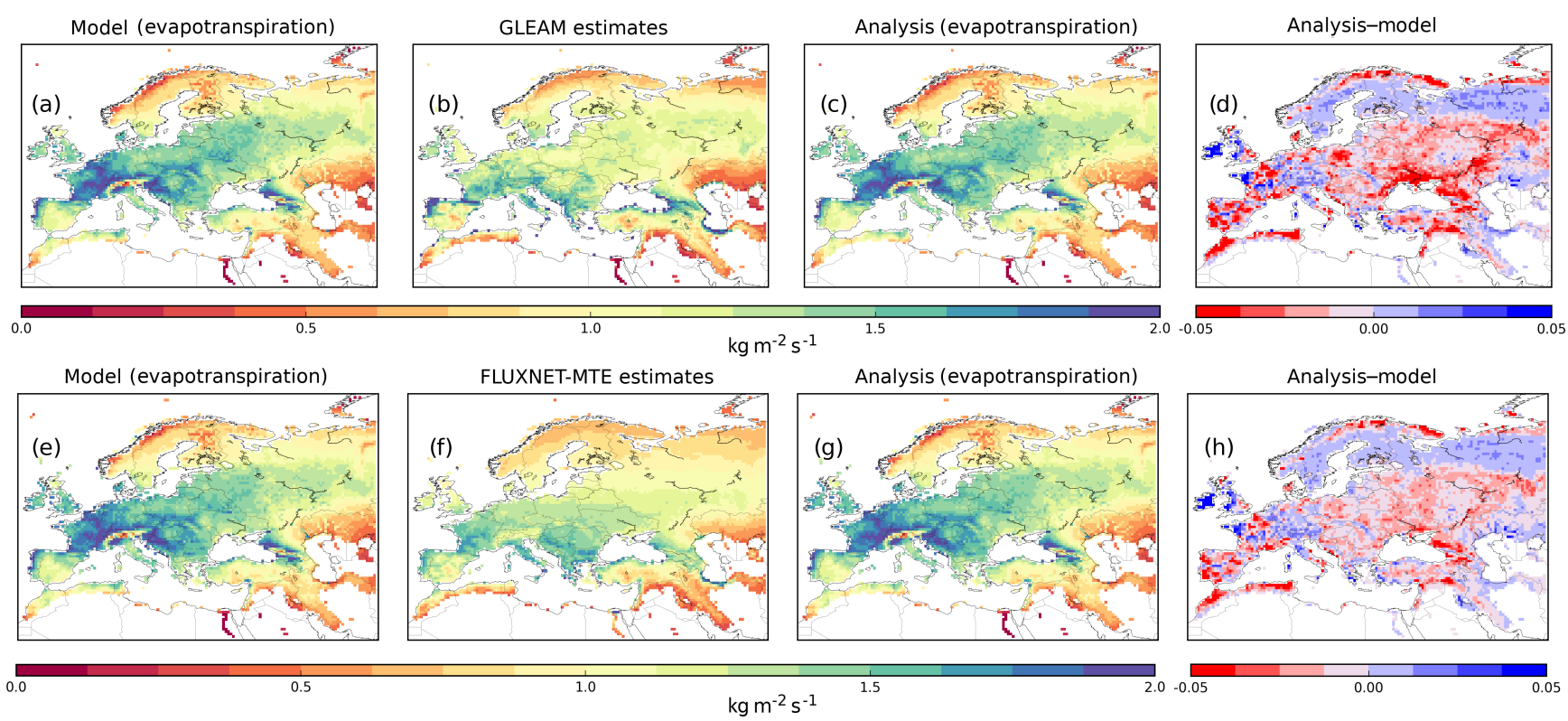

Figure 12. Top row: maps of averaged evapotranspiration taken over 2000-2012 from (a) the model (i.e open loop), (b) the GLEAM estimates, (c) the analysis and (d) differences between the analysis and model. Bottom row: maps of averaged evapotranspiration taken over 2000-2011 from (a) the model (i.e open loop), (b) FLUXNET-MTE estimates, (c) the analysis and (d) differences between the analysis and model.
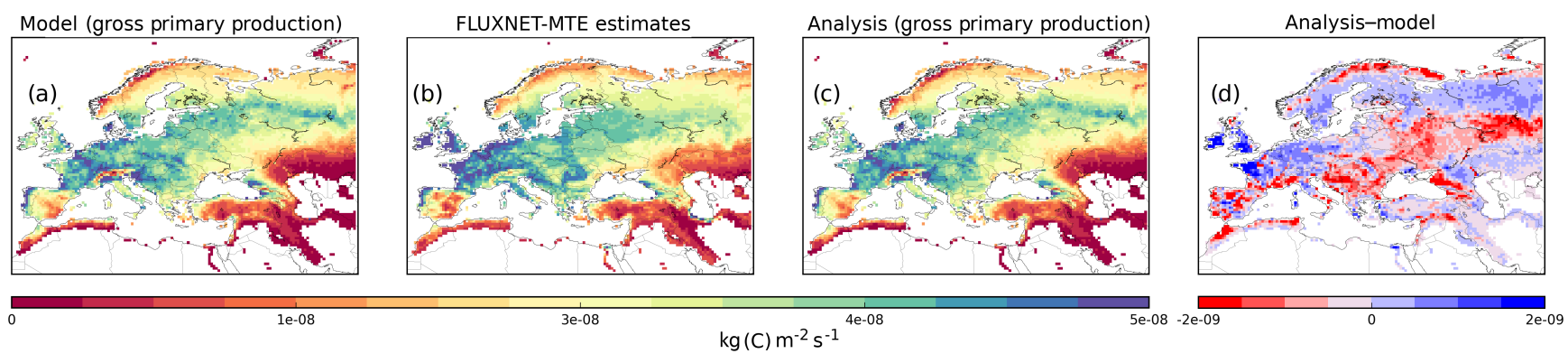

Figure 13. Maps of averaged gross primary production taken over 2000-2011 from (a) the model (i.e open loop), (b) FLUXNET-MTE estimates, (c) the analysis and (d) differences between the analysis and model.

assimilation of SSM and LAI there is a clear improvement in the GPP representation for RMSD and correlation with a systematic seasonal decrease and increase of the scores, respectively. Over the whole domain, 79 and $90 \%$ of the grid points present better RMSD and correlation values, respectively, after assimilation with respect to the FLUXNET-MTE estimates of GPP.

\section{Discussion}

\subsection{Towards different data assimilation techniques to improve the analysis}

This study introducing the LDAS-Monde is based on a simplified version of an extended Kalman filter. Although a version of an ensemble Kalman filter is available (EnKF,
Evensen, 1994), to date SEKF is the most mature technique developed for land surface data assimilation within SURFEX. Many studies using SURFEX exposed the strengths and weaknesses of this technique (Mahfouf et al., 2009; Albergel et al., 2010., Draper et al., 2011; Barbu et al., 2011, 2014; Duerinckx et al., 2015; Fairbairn et al., 2015, 2017). The SEKF relies on accurate linear assumptions in deriving the Jacobians. Draper et al. (2009), Duerinckx et al. (2015) and Fairbairn et al. (2015) pointed out that outliers in Jacobian's values may occur under specific conditions (e.g. close to threshold values such as the wilting point and field capacity for soil moisture), possibly leading to instabilities in the analysis. Those outliers in the Jacobian's values were, however, obtained using the force-restore version of the ISBA LSM with three layers of soil and not with the diffusion soil scheme: ISBA-Dif. In such configurations they used 

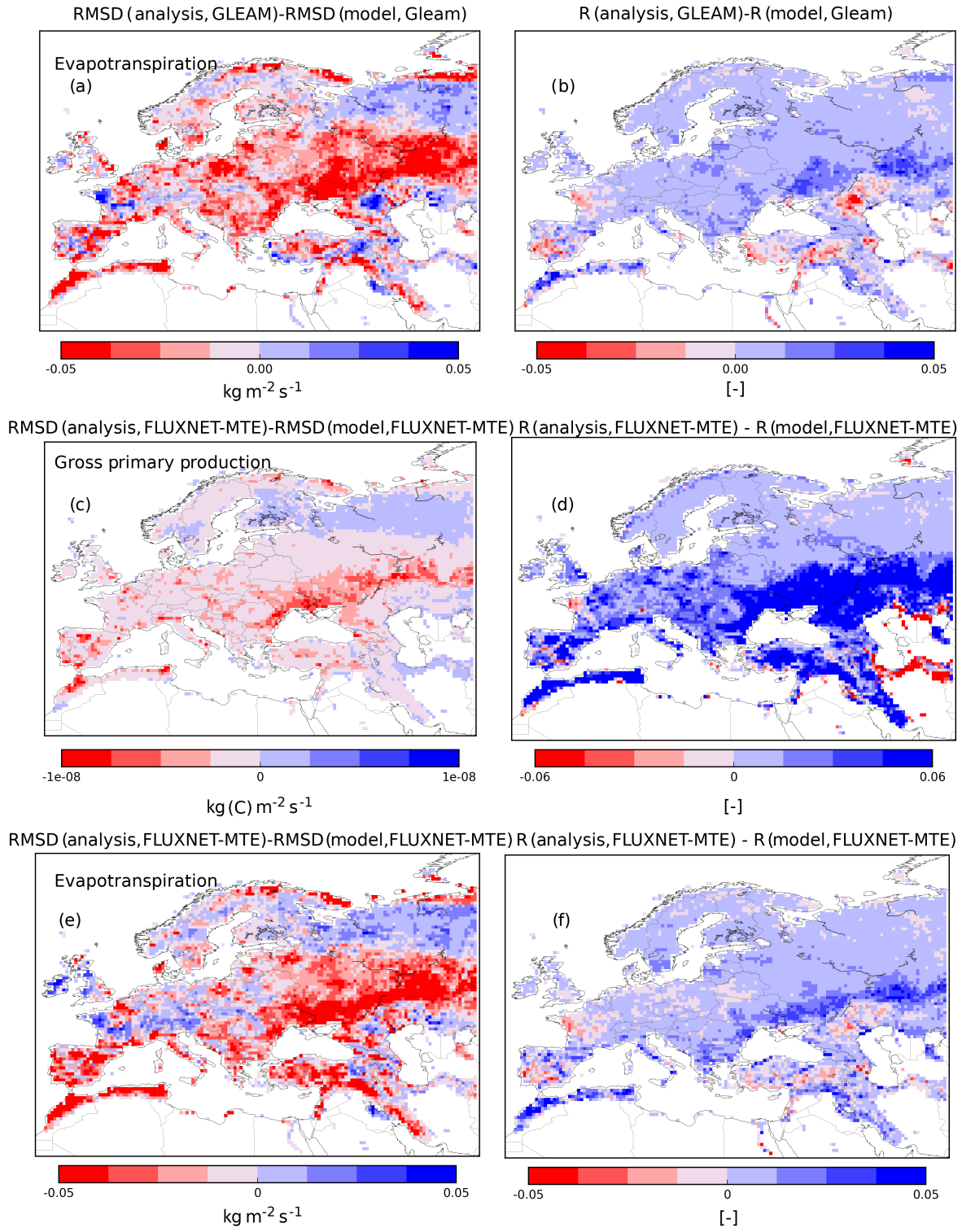

Figure 14. RMSD (a) and correlation (b) differences between analysed (modelled) evapotranspiration and GLEAM estimates over 20002012. Panels (c, d) are similar to (a, b) for carbon mass flux out of the atmosphere due to gross primary production (GPP) from the analysis (model), and FLUXNET-MTE GPP estimates over 2000-2011. Finally, panels (e, f) are similar to (a, b) for analysed (modelled) evapotranspiration and FLUXNET-MTE evapotranspiration estimates over 2000-2011.

only one control variable related to soil moisture; the second layer of soil was a thick layer representing all the rootzone $\left(w_{2}-\mathrm{RZ}\right)$ while the model equivalent was the very thin top layer $(\sim 1 \mathrm{~cm})$. Thus $\frac{\partial \mathrm{SSM}^{t}}{\partial w_{2}-\mathrm{RZ}^{0}}$ Jacobians, representing the impact of perturbing $w_{2}$ (i.e. the whole root-zone) on SSM $(\sim 1 \mathrm{~cm})$ can be quite different compared to those obtained using the soil diffusion scheme and presented in this study (e.g. where $w_{2}$ and SSM representing the same depth; $1-$ $4 \mathrm{~cm}$ ). For instance, $\frac{\partial \mathrm{SSM}^{t}}{\partial w_{2}-\mathrm{RZ}^{0}}$ Jacobians exhibit a rather large proportion of negative values, as illustrated by Fig. 10 of Fairbairn et al. (2017) and discussed in Parrens et al. (2014).
Very few negative Jacobian values are obtained with the diffusion soil scheme (as in Fig. 4) over Europe for 2000-2012. The SEKF is also limited in correcting errors from the atmospheric forcing uncertainty making the model too reliant on the chosen forcing. Alternatively an EnKF, which relies on the ensemble spread to capture background errors, can be modified to stochastically capture both model and precipitation errors (Maggioni et al., 2012; Carrera et al., 2015). The use of an EnKF within LDAS-Monde is currently under investigation at Météo-France. Alternatively, particle filters could provide a means to capture non-Gaussian errors (e.g. Moradkhani et al., 2012). 


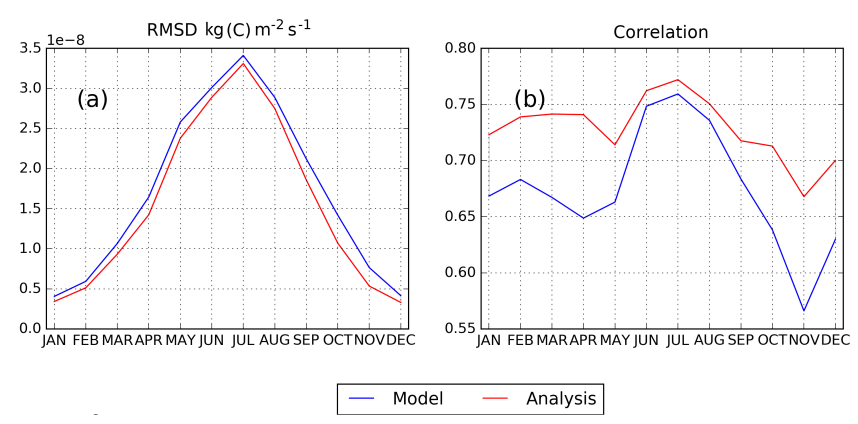

Figure 15. Seasonal (a) RMSD and (b) correlation values between the Carbon mass flux out of the atmosphere due to Gross Primary Production on land from the open loop, analysis and FLUXNETMTE estimates over 2000-2011.

The performance of an analysis scheme depends on appropriate statistics for background and observation errors. Wrongly specified error parameterization may negatively affect the analysis. The main objective of this study was to present the newly developed LDAS-Monde while the statistics for background and observation errors were obtained from the literature. Soil moisture observations and background errors were scaled using the open-loop soil moisture dynamical range. This accounts for texture-based spatial variability in the error and assumes that the soil moisture errors and the dynamic range have a linear relationship. Time correlations in the errors have also been neglected in this study, which are likely to occur in reality. It is also possible to employ an a posteriori diagnostic to estimate observation errors, such as the statistics of the innovations (observations minus background) (Andersson, 2003; Mahfouf et al., 2007). This approach has been successfully applied by Barbu et al. (2011) in a point-scale experiment to obtain seasonal error variability; the approach does not provide objective estimates of the observational errors but assesses the sub-optimality of the analysis. Future work will investigate having spatially and temporally variant observations errors, based on statistical methods already applied to the ESA CCI SSM dataset such as triple collocation (Dorigo et al., 2015) or error decomposition (Su et al., 2016).

Having LAI estimates every 10 days while using $24 \mathrm{~h}$ assimilation window may also trigger analysis discrepancies, as between two LAI assimilations the system relies only on SSM assimilation. When a large analysis update occurs on LAI (from the assimilation of LAI), it then tends to go back towards the model states in the successive days before being constrained again by the next observations. For instance, in winter most of the $\frac{\partial \mathrm{LAI}^{t}}{\partial \mathrm{LAI}^{0}}$ Jacobians are equal (or close) to zero and therefore the analysis update caused the LAI to return almost instantaneously to the incorrect LAI minimum value. This issue could be addressed using longer assimilation windows, from 10 days up to 1 month (e.g. as in Jarlan et al., 2008) where different data assimilation techniques could be used (e.g. variational methods to obtain a best fit between several observations). An alternative could be to keep a 1-day assimilation window and use smoothing techniques (e.g. Munier et al., 2014) to keep the benefit of the analysis update by propagating the error covariance forward up to the next available observation.

\subsection{Can better use of the observations improve the analysis?}

\subsubsection{Towards a better use of GEOV1 leaf area index}

SURFEX_v8.0 does not use any crop-specific parameterization, which would be required to simulate the crop grain yield formation. In addition, the simulations of photosynthesis and vegetation growth do not take into account certain factors impacting the long-term agricultural production (e.g. changes in agricultural practices, diseases, pests, crop migration, the grain formation and crop cultivars). However, previous studies (Calvet et al., 2012; Canal et al., 2014) showed that agricultural statistics such as grain yields can be used to benchmark SURFEX development in representing the above-ground biomass inter-annual variability. A strong positive impact from the assimilation of SSM and LAI on the representation of above-ground biomass inter-annual variability has been highlighted in this study. The impact on river discharge representation is only small (Sect. 3.3). Improvements are, however, expected from a better representation in the model of vegetation parameters such as LAI (e.g. Szczypta et al., 2014). Although the analysis is efficient in correcting LAI, high RMSD values remain, particularly during the senescence phase when SURFEX-CTRIP over-estimates LAI over a large part of Europe. RMSD and correlations with GEOV1 and SURFEX-CTRIP still expose a strong seasonal dependency after the analysis (red line in Fig. 2) which is mainly attributed to model errors. The GEOV1 estimates have been shown to exhibit some realistic environmental features that are not, or are poorly, simulated by the model (Fairbairn et al., 2017). Therefore, it was decided not to rescale the GEOV1 estimates to the model climatology.

Figure 2 also suggests that the minimum LAI values used as model parameters (see Sect. 2.1.1) should be revisited because such large differences are not desirable, particularly when the vegetation is dormant. Another caveat of this study is the use of a single LAI value for all vegetation types that are represented in SURFEX-CTRIP. As detailed in Barbu et al. (2014), the Kalman gain is calculated for each individual vegetation type (patch). The analysis increment is added to the background for each patch, producing a patch-dependent analysis update. The patch dependence is introduced in the Kalman gain via the Jacobian elements. The possibility of having LAI estimates for each type of vegetation is under investigation and has the capacity of overcoming the two above-mentioned weaknesses. Re- 
cently, the GEOV1 LAI data have been disaggregated following a Kalman filtering technique developed by Carrer et al. (2014). This enables the LAI signal for each patch to be separated within the pixel, which provides a dynamic patchdependent estimate of the assimilated LAI within the pixel (Munier et al., 2017). From the individual estimates over 1999-2015, minimum LAI values have also been used to update the model parameterization. Preliminary results from assimilating disaggregated LAI time series and using new LAI minimum values (not shown) suggest better representation of vegetation variables such as LAI and above-ground biomass as well as an enhanced representation of river discharge compared to an open-loop simulation using the former LAI minimum values. Better performances from the assimilation of disaggregated LAI are also expected on the representation of evapotranspiration.

\subsubsection{Towards a better use of microwave satellite observations for soil moisture}

ESA CCI SM is based on multiple microwave sources from space, namely passive radiometer brightness temperature $\left(T_{\mathrm{b}}\right)$ observations and active radar backscatter $\left(\sigma_{\mathrm{o}}\right)$ observations. As they are both indirectly related to soil moisture, retrieval methods making use of, for example, radiative transfer model (for $T_{\mathrm{b}}$, Kerr et al., 2012) or change-detection approaches (for $\sigma_{\mathrm{o}}$, Wagner et al., 1999) are usually required to transform $T_{\mathrm{b}}$ and $\sigma_{\mathrm{o}}$ into soil moisture values that can be assimilated in LSMs. Despite the proven record of assimilating retrieved soil moisture from point scale to regional and continental scale (e.g. Albergel et al., 2010; Draper et al., 2012; Matgen et al., 2012; De Rosnay et al., 2013; Barbu et al., 2014; Wanders et al., 2014; Ridler et al., 2014), there is an increasing tendency towards the direct assimilation of $T_{\mathrm{b}}$ and $\sigma_{\mathrm{o}}$ observations (De Lannoy et al., 2013; Han et al., 2014; Lievens et al., 2015, 2016). Retrieval methods usually make use of land surface parameters and auxiliary information, such as vegetation, texture and temperature, possibly proving inconsistencies with specific model simulations (which also include these parameters but potentially from different sources). Also, if retrievals and model simulations rely on similar types of auxiliary information, their errors may be cross-correlated, potentially degrading the system performance (De Lannoy and Reichle, 2016). The direct assimilation of $T_{\mathrm{b}}$ and $\sigma_{\mathrm{o}}$ observations requires that the LSM is coupled to a radiative transfer model that serves as a forward operator for predicting $\sigma_{\mathrm{o}}$ and/or $T_{\mathrm{b}}$. It has the advantage of allowing for consistent parameters and auxiliary inputs between the model simulations and the radiative transfer model, avoiding cross-correlated errors. The development of a forward operator for $\sigma_{\mathrm{o}}$ from active microwave instruments is under way at Météo-France; it will allow vegetation effects to be accounted for in the signal using the vegetation information content of $\sigma_{\mathrm{o}}$.

\section{Conclusions}

This study provides an assessment of the LDAS-Monde implementation to increase monitoring accuracy for land surface variables over the Europe-Mediterranean area. Satellitederived surface soil moisture and leaf area index are assimilated over 2000-2012 in the $\mathrm{CO}_{2}$-responsive and multilayer diffusion scheme version of the ISBA land surface model coupled with the CTRIP hydrological system. Joint assimilation of leaf area index and surface soil moisture has been shown to efficiently improve the representation of aboveground biomass, gross primary production and evapotranspiration, while having a neutral to positive impact on river discharge. To our knowledge, LDAS-Monde is the only system able to sequentially assimilate vegetation products together with soil moisture observations. LDAS-Monde permits an efficient monitoring of various land surface variables and has a powerful potential in monitoring extreme events such as agricultural droughts on a global scale.

The analysis of the extended Kalman filter observation operator Jacobians permitted identification of both seasonal and soil depth effects of the assimilation on ISBA. A clear added value of the assimilation has been highlighted based on agricultural statistics over France, and evapotranspiration and gross primary production observation-based estimates over the whole domain. More analysis impact could, however, be expected on variables such as river discharge. Studies focusing on a better use of the observations along with other data assimilation techniques such as the ensemble Kalman filter are currently under way. Recent studies discussed in the previous section suggest that the direct assimilation of microwave observations of $T_{\mathrm{b}}$ and $\sigma_{\mathrm{o}}$ instead of level 2 or 3 soil moisture products could leads to better results. The development of a forward operator for $\sigma_{\mathrm{o}}$ from active microwave instruments is under way. The long-term confrontation of model and observations on continental scale prior to the assimilation has also highlighted parameterisation issues such as the minimum leaf area index values used as threshold when the vegetation is dormant. The GEOV1 leaf area index estimates permit new thresholds to be set up for the different vegetation patches used in ISBA thanks to the development of a disaggregated product resulting in new leaf area index estimates, different for each patch. The assimilation of this new product is also promising.

Code availability. LDAS-Monde is a part of the ISBA land surface model and is available as open source via the surface modelling platform called SURFEX. SURFEX can be downloaded freely at http: //www.umr-cnrm.fr/surfex/ using a CECILL-C Licence (a French equivalent to the L-GPL licence; http://www.cecill.info/licences/ Licence_CeCILL-C_V1-en.txt). It is updated at a relatively low frequency (every 3 to 6 months). If more frequent updates are needed, or if what is required is not in Open-SURFEX (DrHOOK, FA/LFI formats, GAUSSIAN grid), you are invited to follow the procedure to get a SVN account and to access real-time modifications of the 
code (see the instructions at the first link). The developments presented in this study stemmed on SURFEX version 8.0 and are now part of the version 8.1 (revision number 4621).

Acknowledgements. The work of Simon Munier was supported by European Union Seventh Framework Programme (FP7/2007-2013) under grant agreement no. 603608, "Global Earth Observation for integrated water resource assessment" (eartH2Observe). The work of Hélène Dewaele was supported by CNES and by Météo-France. The work of Emiliano Gelati was supported by the French REMEMBER project (ANR 2012 SOC\&ENV 001) within the HYMEX initiative. Wouter Dorigo is co-funded by the "TU Wien Wissenschaftspreis 2015", a personal grant awarded by the Vienna University of Technology. The authors acknowledge ESA's Climate Change Initiative for Soil Moisture (Contract No. 4000104814/11/I-NB and 4000112226/14/I-NB) and the EU FP7 EartH2Observe project (grant agreement number 331603608 ) for supporting the development and evolution of the ESA CCI SM product. The authors would like to thank the Copernicus Global Land Service for providing the satellite-derived LAI products.

Edited by: Christoph Müller

Reviewed by: Patricia de Rosnay and one anonymous referee

\section{References}

Agreste: http://agreste.agriculture.gouv.fr/page-d-accueil/article/ donnees-en-ligne, last access: December 2016.

Albergel, C., Rüdiger, C., Carrer, D., Calvet, J.-C., Fritz, N., Naeimi, V., Bartalis, Z., and Hasenauer, S.: An evaluation of ASCAT surface soil moisture products with in-situ observations in Southwestern France, Hydrol. Earth Syst. Sci., 13, 115-124, https://doi.org/10.5194/hess-13-115-2009, 2009.

Albergel, C., Calvet, J.-C., Mahfouf, J.-F., Rüdiger, C., Barbu, A. L., Lafont, S., Roujean, J.-L., Walker, J. P., Crapeau, M., and Wigneron, J.-P.: Monitoring of water and carbon fluxes using a land data assimilation system: a case study for southwestern France, Hydrol. Earth Syst. Sci., 14, 1109-1124, https://doi.org/10.5194/hess-14-1109-2010, 2010.

Albergel, C., Dorigo, W., Reichle, R. H., Balsamo, G., de Rosnay, P., Munoz-Sabater, J., Isaksen, L., de Jeu, R., and Wagner, W.: Skill and global trend analysis of soil moisture from reanalyses and microwave remote sensing, J. Hydrometeorol., 14, 1259-1277, https://doi.org/10.1175/JHM-D-12-0161.1, 2013a.

Albergel, C., Dorigo, W., Balsamo, G., Muñoz-Sabater, J., de Rosnay, P., L. Isaksen, Brocca, L., R. de Jeu and Wagner, W.: Monitoring multi-decadal satellite earth observation of soil moisture products through land surface reanalyses, Remote Sens. Environ., 138, 77-89, https://doi.org/10.1016/j.rse.2013.07.009, 2013b.

Andersson, E.: Modelling of innovation statistics, Proceedings of Workshop on recent developments in data assimilation for atmosphere and ocean, ECMWF, Reading, UK, 8-12 September 2003, 153-164, 2003.

Balsamo, G., Bouyssel, F., and Noilhan, J.: A simplified bidimensional variational analysis of soil moisture from screen- level observations in a mesoscale numerical weather prediction model, Q. J. Roy. Meteor. Soc., 130, 895-915, 2004.

Barbu, A. L., Calvet, J.-C., Mahfouf, J.-F., Albergel, C., and Lafont, S.: Assimilation of Soil Wetness Index and Leaf Area Index into the ISBA-A-gs land surface model: grassland case study, Biogeosciences, 8, 1971-1986, https://doi.org/10.5194/bg-8-19712011, 2011.

Barbu, A. L., Calvet, J.-C., Mahfouf, J.-F., and Lafont, S.: Integrating ASCAT surface soil moisture and GEOV1 leaf area index into the SURFEX modelling platform: a land data assimilation application over France, Hydrol. Earth Syst. Sci., 18, 173-192, https://doi.org/10.5194/hess-18-173-2014, 2014.

Baret, F., Weiss, M., Lacaze, R., Camacho, F., Makhmared, H., Pacholczyk, P., and Smetse, B.: GEOV1: LAI and FAPAR essential climate variables and FCOVER global time series capitalizing over existing products, Part 1: Principles of development and production, Remote Sens. Environ., 137, 299-309, 2013.

Barichivich, J., Briffa, K. R., Myneni, R., Van der Schrier, G., Dorigo, W., Tucker, C. J. et al.Temperature and snow-mediated moisture controls of summer photosynthetic activity in northern terrestrial ecosystems between 1982 and 2011, Remote Sens., 6, 1390-1431, 2014.

Bauer-Marschallinger, B., Dorigo, W. A., Wagner, W., and van Dijk, A. I. J. M. How oceanic oscillation drives soil moisture variations over mainland Australia: an analysis of 32 years of satellite observations, J. Climate, 26, 10159-10173, 2013.

Beer, C., Reichstein, M., Tomelleri, E., Ciais, P., Jung, M., Carvalhais, N., Rödenbeck, C., Arain, M. A., Baldocchi, D., Bonan, G. B., Bondeau, A., Cescatti, A., Lasslop, G., Lindroth, A., Lomas, M., Luyssaert, S., Margolis, H., Oleson, K. W., Roupsard, O., Veenendaal, E., Viovy, N., Williams, C., Woodward, F. I., and Papale, D.: Terrestrial gross carbon dioxide uptake: global distribution and covariation with climate, Science, 329, 834-838, https://doi.org/10.1126/science.1184984, 2010.

Bonan, G. B., Lawrence, P. J., Oleson, K. W., Levis, S., Jung, M., Reichstein, M., Lawrence, D. M., and Swenson, S. C.: Improving canopy processes in the Community Land Model version 4 (CLM4) using global flux fields empirically inferred from FLUXNET data, J. Geophys. Res., 116, G02014, https://doi.org/10.1029/2010JG001593, 2011.

Boone, A. and Etchevers, P.: An intercomparison of three snow schemes of varying complexity coupled to the same land-surface model: local scale evaluation at an Alpine site, J. Hydrometeorol., 2, 374-394, 2001.

Boone, A., Masson, V., Meyers, T., and Noilhan, J.: The influence of the inclusion of soil freezing on simulations by a soil vegetationatmosphere transfer scheme, J. Appl. Meteorol., 39, 1544-1569, 2000.

Boussetta, S., Balsamo, G., Dutra, E., Beljaars, A. and Albergel, C.: Assimilation of surface albedo and vegetation states from satellite observations and their impact on numerical weather prediction, Remote Sens. Environ., 163, 111-126, https://doi.org/10.1016/j.rse.2015.03.009, 2015.

Brooks, R. H. and Corey, A. T.: Properties of porous media affecting fluid flow, J. Irrig. Drain. Div. Am. Soc. Civ. Eng., 17, 187-208, 1966.

Calvet, J.-C., and Soussana, J.-F.: Modelling $\mathrm{CO}_{2}$-enrichment effects using an interactive vegetation SVAT scheme, Agr. Forest Meteorol., 108, 129-152, 2001. 
Calvet, J.-C., Noilhan, J., Roujean, J.-L., Bessemoulin, P., Cabelguenne, M., Olioso, A., and Wigneron, J.-P.: An interactive vegetation SVAT model tested against data from six contrasting sites, Agr. Forest Meteorol., 92, 73-95, 1998.

Calvet, J.-C., Rivalland, V., Picon-Cochard, C., and Guehl, J.M.: Modelling forest transpiration and $\mathrm{CO}_{2}$ fluxes - response to soil moisture stress, Agr. Forest Meteorol., 124, 143-156, https://doi.org/10.1016/j.agrformet.2004.01.007, 2004.

Calvet, J.-C., Lafont, S., Cloppet, E., Souverain, F., Badeau, V., and Le Bas, C.: Use of agricultural statistics to verify the interannual variability in land surface models: a case study over France with ISBA-A-gs, Geosci. Model Dev., 5, 37-54, https://doi.org/10.5194/gmd-5-37-2012, 2012.

Canal, N., Calvet, J.-C., Decharme, B., Carrer, D., Lafont, S., and Pigeon, G.: Evaluation of root water uptake in the ISBA-A-gs land surface model using agricultural yield statistics over France, Hydrol. Earth Syst. Sci., 18, 4979-4999, https://doi.org/10.5194/hess-18-4979-2014, 2014.

Carrer, D., Meurey, C., Ceamanos, X., Roujean, J.-L., Calvet, J.C., and Liu, S.: Dynamic mapping of snow-free vegetation and bare soil albedos at global $1 \mathrm{~km}$ scale from 10 year analysis of MODIS satellite products, Remote Sens. Environ., 140, 420432, https://doi.org/10.1016/j.rse.2013.08.041, 2014.

Carrera, M., Bélair, S., and Bilodeau, B.: The Canadian Land Data Assimilation System (CaLDAS): description and synthetic evaluation study, J. Hydrometeorol., 16, 1293-1294, https://doi.org/10.1175/JHM-D-14-0089.1, 2015.

Carvalhais, N., Forkel, M., Khomik, M., Migliavacca, M., Mu, M., Saatchi, S., Santoro, S., Thurner, M., Weber, U., Ahrens, B., Beer, C., Cescatti, A., Randerson, J. T. and Reichstein, M.: Global covariation of carbon turnover times with climate in terrestrial ecosystems, Nature, 514, 213-217, 2014.

Chevallier, F. and Mahfouf, J.-F.: Evaluation of Jacobians of infrared models for variational assimilation, J. Appl. Meteorol., 40, 1445-1462, https://doi.org/10.1175/15200450(2001)040<1445:EOTJOI >2.0.CO;2, 2001.

Ciais, P., Reichstein, M., Viovy, N., Granier, A., Ogee, J., Allard, V., Aubinet, M., Buchmann, N., Bernhofer, C., Carrara, A., Chevallier, F., De Noblet, N., Friend, A. D., Friedlingstein, P., Grunwald, T., Heinesch, B., Keronen, P., Knohl, A., Krinner, G., Loustau, D., Manca, G., Matteucci, G., Miglietta, F., Ourcival, J. M., Papale, D., Pilegaard, K., Rambal, S., Seufert, G., Soussana, J. F., Sanz, M. J., Schulze, E. D., Vesala, T., and Valentini, R.: Europewide reduction in primary productivity caused by the heat and drought in 2003, Nature, 437, 529-533, 2005.

Decharme, B., Alkama, R., Douville, H., Becker, M., and Cazenave, A.: Global evaluation of the ISBA-TRIP continental hydrologic system, Part 2: Uncertainties in river routing simulation related to flow velocity and groundwater storage, J. Hydrometeorol., 11, 601-617, 2010.

Decharme, B., Boone, A., Delire, C., and Noilhan, J.: Local evaluation of the Interaction between soil biosphere atmosphere soil multilayer diffusion scheme using four pedotransfer functions, J. Geophys. Res., 116, D20126, https://doi.org/10.1029/2011JD016002, 2011.

Decharme, B., Alkama, R., Papa, F., Faroux, S., Douville, H., and Prigent, C.: Global offline evaluation of the ISBA-TRIP flood model, Clim. Dynam., 38, 1389-1412, https://doi.org/10.1007/s00382-011-1054-9, 2012.
Decharme, B., Martin, E., and Faroux, S.: Reconciling soil thermal and hydrological lower boundary conditions in land surface models, J. Geophys. Res.-Atmos., 118, 7819-7834, https://doi.org/10.1002/jgrd.50631, 2013.

Decharme, B., Brun, E., Boone, A., Delire, C., Le Moigne, P., and Morin, S.: Impacts of snow and organic soils parameterization on northern Eurasian soil temperature profiles simulated by the ISBA land surface model, The Cryosphere, 10, 853-877, https://doi.org/10.5194/tc-10-853-2016, 2016.

Dee, D. P., Uppala, S. M., Simmons, A. J., Berrisford, P., Poli, P., Kobayashi, S., Andrae, U., Balmaseda, M. A., Balsamo, G., Bauer, P., Bechtold, P., Beljaars, A. C. M., van de Berg, L., Bidlot, J., Bormann, N., Delsol, C., Dragani, R., Fuentes, M., Geer, A. J., Haimberger, L., Healy, S. B., Hersbach, H., Hólm, E. V., Isaksen, L., Kallberg, P., Köhler, M., Matricardi, M., McNally, A. P., Monge-Sanz, B. M., Morcrette, J. J., Park, B. K., Peubey, C., de Rosnay, P., Tavolato, C., Thépaut, J.-N., and Vitart, F.: The ERA-Interim reanalysis: configuration and performance of the data assimilation system, Q. J. Roy. Meteor. Soc., 137, 553-597, https://doi.org/10.1002/qj.828, 2011.

de Jeu, R. A. M., Wagner, W., Holmes, T. R. H., Dolman, A. J., van de Giesen, N. C., and Friesen, J.: Global soil moisture patterns observed by space borne microwave radiometers and scatterometers, Surv. Geophys., 29, 399-420, 2008.

de Lannoy, G. J. M., Reichle, R. H., and Pauwels, V. R. N.: Global calibration of the GEOS-5 L-band microwave radiative transfer model over nonfrozen land using SMOS observations, J. Hydrometeorol., 14, 765-785, 2013.

de Lannoy, G. J. M. and Reichle, R. H.: Global assimilation of multiangle and multipolarization SMOS brightness temperature observations into the GEOS-5 catchment Land Surface Model for soil moisture estimation, J. Hydrometeorol., 17, 669-691, 2016.

de Rosnay, P., Drusch, M., Vasiljevic, D., Balsamo, G., C. Albergel and Isaksen, L.: A simplified extended Kalman filter for the global operational soil moisture analysis at ECMWF, Q. J. Roy. Meteor. Soc., 139, 1199-1213, 2013.

de Rosnay, P., Balsamo, G., Albergel, C., Muñoz-Sabater, J. and Isaksen, L.: Initialisation of land surface variables for numerical weather prediction, Surv. Geophys., 35, 607-621, 2014.

Dewaele, H., Munier, S., Albergel, C., Planque, C., Laanaia, N., Carrer, D., and Calvet, J.-C.: Parameter optimisation for a better representation of drought by LSMs: inverse modelling vs. sequential data assimilation, Hydrol. Earth Syst. Sci., 21, 48614878, https://doi.org/10.5194/hess-21-4861-2017, 2017.

Dharssi, I., Bovis, K. J., Macpherson, B., and Jones, C. P.: Operational assimilation of ASCAT surface soil wetness at the Met Office, Hydrol. Earth Syst. Sci., 15, 2729-2746, https://doi.org/10.5194/hess-15-2729-2011, 2011.

Dirmeyer, P. A., Gao, X., Zhao, M., Guo, Z., Oki, T., and Hanasaki 2006, N.: The Second Global Soil Wetness Project (GSWP2): multi-model analysis and implications for our perception of the land surface, B. Am. Meteorol. Soc., 87, 1381-1397, https://doi.org/10.1175/BAMS-87-10-1381, 2006.

Dorigo, W., Wagner, W., Albergel, C. Albrecht, F., Balsamo, G., Brocca, L., Chung, D., Ertl, M., Forkel, M., Gruber, A., Haas, E., Hamer, P. D., Hirschi, M., Ikonen, J., de Jeu, R., Kidd, R., William Lahoz g, Liu, Y. Y., Miralles, D., Mistelbauer, T., Nicolai-Shaw, N., Parinussa, R., Pratola, C., Reimer, C., van der Schalie, R., Seneviratne, S. I., Smolander, T., and Lecomte, P.: 
ESA CCI soil moisture for improved Earth system understanding: state-of-the art and future directions, Remote Sens. Environ., 201, RSE-10331, https://doi.org/10.1016/j.rse.2017.07.001, 2017.

Dorigo, W. A., Gruber, A., De Jeu, R. A. M., Wagner, W., Stacke, T., Loew, A., C. Albergel, Brocca, L., Chung, D., Parinussa, R. M., and Kidd, R.: Evaluation of the ESA CCI soil moisture product using ground-based observations, Remote Sens. Environ., 162, 380-395, https://doi.org/10.1016/j.rse.2014.07.023, 2015.

Draper, C., Mahfouf, J.-F., Calvet, J.-C., Martin, E., and Wagner, W.: Assimilation of ASCAT near-surface soil moisture into the SIM hydrological model over France, Hydrol. Earth Syst. Sci., 15, 3829-3841, https://doi.org/10.5194/hess-15-3829-2011, 2011.

Draper, C. S., Mahfouf, J.-F., and Walker, J. P.: An EKF assimilation of AMSR-E soil moisture into the ISBA land surface scheme, J. Geophys. Res., 114, D20104, https://doi.org/10.1029/2008JD011650, 2009.

Draper, C. S., Reichle, R. H., De Lannoy, G. J. M., and Liu, Q.: Assimilation of passive and active microwave soil moisture retrievals, Geophys. Res. Lett., 39, L04401, https://doi.org/10.1029/2011GL050655, 2012.

Drusch, M., Wood, E. F., and Gao, H.: Observations operators for the direct assimilation of TRMM microwave imager retrieved soil moisture, Geophys. Res. Lett., 32, L15403, https://doi.org/10.1029/2005GL023623, 2005.

Duerinckx, A., Hamdi, R., Mahfouf, J.-F., and Termonia, P.: Study of the Jacobian of an extended Kalman filter for soil analysis in SURFEXv5, Geosci. Model Dev., 8, 845-863, https://doi.org/10.5194/gmd-8-845-2015, 2015.

Evensen, G.: Sequential data assimilation with a nonlinear quasigeostrophic model using Monte Carlo methods to forecast error statistics, J. Geophys. Res, 99, 10 143-10 162, 1994.

Fairbairn, D., Barbu, A. L., Mahfouf, J.-F., Calvet, J.-C., and Gelati, E.: Comparing the ensemble and extended Kalman filters for in situ soil moisture assimilation with contrasting conditions, Hydrol. Earth Syst. Sci., 19, 4811-4830, https://doi.org/10.5194/hess-19-4811-2015, 2015.

Fairbairn, D., Barbu, A. L., Napoly, A., Albergel, C., Mahfouf, J.F., and Calvet, J.-C.: The effect of satellite-derived surface soil moisture and leaf area index land data assimilation on streamflow simulations over France, Hydrol. Earth Syst. Sci., 21, 20152033, https://doi.org/10.5194/hess-21-2015-2017, 2017.

Fillion, L. and Mahfouf, J.-F.: Jacobians of an operational prognostic cloud scheme, Mon. Weather Rev., 131, 2838-2856, 2003.

Garand, L., Turner, D. S., Larocque, M., Bates, J., Boukabara, S., Brunel, P., Chevallier, F., Deblonde, G., Engelen, R., Hollingshead, M., Jackson, D., Jedlovec, G., Joiner, J., Kleespies, T., McKague, McMillin, D. S., L., Moncet, J.-L., Pardo, J. R., Rayer, P. J., Salathe, E., Saunders, R., Scott, N. A., Van Delst, P., and Woolf, H.: Radiance and Jacobian intercomparison of radiative transfer models applied to HIRS and AMSU channels, J. Geophys. Res., 106, 24017-24031, https://doi.org/10.1029/2000JD000184, 2001.

Gibelin, A.-L., Calvet, J.-C., Roujean, J.-L., Jarlan, L., and Los, S. O.: Ability of the land surface model ISBA-Ags to simulate leaf area index at global scale: comparison with satellite products, J. Geophys. Res., 111, 1-16, https://doi.org/10.1029/2005JD006691, 2006.
Greve, P., Orlowsky, B., Mueller, B., Sheffield, J., Reichstein, M., and Seneviratne, S. I.: Global assessment of trends in wetting and drying over land, Nat. Geosci., 7, 716-721, https://doi.org/10.1038/ngeo2247, 2014.

Gruber, A., Su, C. H., Zwieback, S., Crow, W. T., Wagner, W., and Dorigo, W.: Recent advances in (soil moisture) triple collocation analysis, Int. J. Appl. Earth Obs., 45, 200-211, 2016.

Guillod, B. P., Orlowsky, B., Miralles, D. G., Teuling, A. J., and Seneviratne, S. I.: Reconciling spatial and temporal soil moisture effects on afternoon rainfall, Nat. Commun., 6, 6443, https://doi.org/10.1038/ncomms7443, 2015.

Habets, F., Boone, A., Champeaux, J.-L., Etchevers, P., Franchisteguy, L., Leblois, E., Ledoux, E., Le Moigne, P., Martin, E., Morel S., Noilhan, J., Quintana Seguí, P., Rousset Regimbeau, F., and Vienno, P.: The SAFRAN-ISBA-MODCOU hydrometeorological model applied over France, J. Geophys. Res., 113, D06113, https://doi.org/10.1029/2007JD008548, 2008.

Han, X., Hendricks Franssen, H.-J., Montzka, C., and Vereecken, H.: Soil moisture and soil properties estimation in the community land model with synthetic brightness temperature observations, Water Resour. Res., 50, 6081-6105, 2014.

Harris, I., Jones, P. D., Osborn, T. J., and Lister, D. H.: Updated high-resolution grids of monthly climatic observationsthe CRU TS3. Dataset, Int. J. Climatol., 34, 623-642, https://doi.org/10.1002/joc.3711, 2014.

Jackson, R. B., Canadell, J., Ehleringer, J. R., Mooney, H. A., Sala, O. E., and Schulze, E. D.: A global analysis of root distributions for terrestrial biomes, Oecologia, 108, 389-411, https://doi.org/10.1007/BF00333714, 1996.

Jarlan, L., Balsamo, G., Lafont, S., Beljaars, A., Calvet, J.-C., and Mougin, E.: Analysis of leaf area index in the ECMWF land surface model and impact on latent heat and carbon fluxes: application to West Africa, J. Geophys. Res., 113, D24117, https://doi.org/10.1029/2007JD009370, 2008.

Jasechko, S., Sharp, Z. D., Gibson, J. J., Birks, S. J., Yi, Y., and Fawcett, P. J.: Terrestrial water fluxes dominated by transpiration, Nature, 496, 347-350, https://doi.org/10.1038/nature11983, 2013.

Jung, M., Reichstein, M., and Bondeau, A.: Towards global empirical upscaling of FLUXNET eddy covariance observations: validation of a model tree ensemble approach using a biosphere model, Biogeosciences, 6, 2001-2013, https://doi.org/10.5194/bg-6-2001-2009, 2009.

Jung, M., Reichstein, M., Ciais, P., Seneviratne, S. I., Sheffield, J., Goulden, M. L., Bonan, G., Cescatti, A., Chen, J., de Jeu, R., Dolman, A. J., Eugster, W., Gerten, D., Gianelle, D., Gobron, N., Heinke, J., Kimball, J., Law, B. E., Montagnani, L., Mu, Q., Mueller, B., Oleson, K., Papale, D., Richardson, A. D., Roupsard, O., Running, S., Tomelleri, E., Viovy, N., Weber, U., Williams, C., Wood, E., Zaehle, S., and Zhang, K.: Recent decline in the global land evapotranspiration trend due to limited moisture supply, Nature, 467, 951-954, https://doi.org/10.1038/nature09396, 2010.

Jung, M., Reichstein, M., Margolis, H. A., Cescatti, A., Richardson, A. D., Arain, M. A., Arneth, A., Bernhofer, C., Bonal, D., Chen, J., Gianelle, D., Gobron, N., Kiely, G., Kutsch, W., Lasslop, G., Law, B. E., Lindroth, A., Merbold, L., Montagnani, L., Moors, E. J., Papale, D., Sottocornola, M., 
Vaccari, F., and Williams, C.: Global patterns of landatmosphere fluxes of carbon dioxide, latent heat, and sensible heat derived from eddy covariance, satellite, and meteorological observations, J. Geophys. Res., 116, G00J07, https://doi.org/10.1029/2010JG001566, 2011.

Kaminski, T., Knorr, W., Schürmann, G., Scholze, M., Rayner, P. J., Zaehle, S., Blessing, S., Dorigo, W., Gayler, V., Giering, R., Gobron, N., Grant, J., Heimann, M., Hooker-Strout, A., Houweling, S., Kato, T., Kattge, J., Kelley, D., Kemp, S., Koffi, E. N., Kostler, C., Mathieu, P. P., Pinty, B., Reick, C., Rödenbeck, C., Schnur, R., Scipal, K., Sebald, C., Stacke, T., Terwisscha van Scheltinga, A., Vossbeck, M., Widmann, H., and Ziehn, T.: The BETHY/JSBACH carbon cycle data assimilation system: experiences and challenges, J. Geophys. Res.-Biogeo., 118, 14141426, 2013.

Kerr, Y., Waldteufel, P., Richaume, P., Wigneron, J., Ferrazzoli, P., Mahmoodi, A., Al Bitar, A., Cabot, F., Gruhier, C., Juglea, S., Leroux, D., Mialon, A., and Delwart, S.: The SMOS soil moisture retrieval algorithm, IEEE T. Geosci. Remote, 50, 13841403, 2012.

Kochendorfer, J. P. and Ramírez, J. A.: Modeling the monthly mean soil-water balance with a statistical-dynamical ecohydrology model as coupled to a two-component canopy model, Hydrol. Earth Syst. Sci., 14, 2099-2120, https://doi.org/10.5194/hess-142099-2010, 2010.

Lambin, E., Baulies, X., Bockstael, N., Fischer, G., Krug, T., Leemans, R., Moran, E., Rindfuss, R., Sato, Y., Skole, D., Turner II, B., and Vogel, C.: Land Use and Land Cover Change - Implementation strategy, International Geosphere-biosphere Programme Secretariat, Stockholm, IGPB report No. 48, IHPD Report No. 10, 1999.

Lievens, H., Al Bitar, A., Verhoest, N. E. C., Cabot, F., De Lannoy, G. J. M., Drusch, M., Dumedah, G., Hendricks Franssen, H.J., Kerr, Y. H., Kumar Tomer, S., Martens, B., Merlin, O., Pan, M., van den Berg, M. J., Vereecken, H., Walker, J. P., Wood, E. F., and Pauwels, V. R. N.: Optimization of a radiative transfer forward operator for simulating SMOS brightness temperatures over the Upper Mississippi Basin, USA, J. Hydrometeorol., 16, 1109-1134, 2015.

Lievens, H., Martens, B., Verhoest, N. E. C., Hahn, S., Reichle, R. H., Miralles, D. G.: Assimilation of global radar backscatter and radiometer brightness temperature observations to improve soil moisture and land evaporation estimates, Remote Sens. Environ., 189, 194-210, https://doi.org/10.1016/j.rse.2016.11.022, 2016.

Liu, Y. Y., Parinussa, R. M., Dorigo, W. A., De Jeu, R. A. M., Wagner, W., van Dijk, A. I. J. M., McCabe, M. F., and Evans, J. P.: Developing an improved soil moisture dataset by blending passive and active microwave satellite-based retrievals, Hydrol. Earth Syst. Sci., 15, 425-436, https://doi.org/10.5194/hess-15425-2011, 2011.

Liu, Y. Y., Dorigo, W. A., Parinussa, R. M., De Jeu, R. A. M., Wagner, W., McCabe, M. F., Evans, J. P., and Van Dijk, A. I. J. M.: Trend-preserving blending of passive and active microwave soil moisture retrievals, Remote Sens. Environ., 123, 280-297, https://doi.org/10.1016/j.rse.2012.03.014, 2012.

Loew, A., Stacke, T., Dorigo, W., de Jeu, R., and Hagemann, S.: Potential and limitations of multidecadal satellite soil moisture observations for selected climate model evaluation studies, Hydrol.
Earth Syst. Sci., 17, 3523-3542, https://doi.org/10.5194/hess-173523-2013, 2013.

Maggioni, V., Anagnostou, E. N., and Reichle, R. H.: The impact of model and rainfall forcing errors on characterizing soil moisture uncertainty in land surface modeling, Hydrol. Earth Syst. Sci., 16, 3499-3515, https://doi.org/10.5194/hess-16-3499-2012, 2012.

Mahfouf, J.-F., Brasnett, B., and Gagnon, S.: A Canadian precipitation analysis project: description and preliminary results, Atmos. Ocean, 45, 1-17, 2007.

Mahfouf, J.-F., Bergaoui, K., Draper, C., Bouyssel, C., Taillefer, F., and Taseva, L.: A comparison of two offline soil analysis schemes for assimilation of screenlevel observations, J. Geophys. Res., 114, D08105, https://doi.org/10.1029/2008JD011077, 2009.

Martens, B., Miralles, D. G., Lievens, H., van der Schalie, R., de Jeu, R. A. M., Fernández-Prieto, D., Beck, H. E., Dorigo, W. A., and Verhoest, N. E. C.: GLEAM v3: satellite-based land evaporation and root-zone soil moisture, Geosci. Model Dev., 10, 19031925, https://doi.org/10.5194/gmd-10-1903-2017, 2017.

Masson, V., Le Moigne, P., Martin, E., Faroux, S., Alias, A., Alkama, R., Belamari, S., Barbu, A., Boone, A., Bouyssel, F., Brousseau, P., Brun, E., Calvet, J.-C., Carrer, D., Decharme, B., Delire, C., Donier, S., Essaouini, K., Gibelin, A.-L., Giordani, H., Habets, F., Jidane, M., Kerdraon, G., Kourzeneva, E., Lafaysse, M., Lafont, S., Lebeaupin Brossier, C., Lemonsu, A., Mahfouf, J.-F., Marguinaud, P., Mokhtari, M., Morin, S., Pigeon, G., Salgado, R., Seity, Y., Taillefer, F., Tanguy, G., Tulet, P., Vincendon, B., Vionnet, V., and Voldoire, A.: The SURFEXv7.2 land and ocean surface platform for coupled or offline simulation of earth surface variables and fluxes, Geosci. Model Dev., 6, 929-960, https://doi.org/10.5194/gmd-6-929-2013, 2013.

Matgen, P., Fenicia, F., Heitz, S., Plaza, D., de Keyser, R., Pauwels, V. R. N., Wagner, W., and Savenije, H.: Can ASCATderived soil wetness indices reduce predictive uncertainty in well-gauged areas? A comparison with in situ observed soil moisture in an assimilation application, Adv. Water Resour., 44, 49-65, 2012.

Miralles, D. G., Holmes, T. R. H., De Jeu, R. A. M., Gash, J. H., Meesters, A. G. C. A., and Dolman, A. J.: Global land-surface evaporation estimated from satellite-based observations, Hydrol. Earth Syst. Sci., 15, 453-469, https://doi.org/10.5194/hess-15453-2011, 2011.

Miralles, D. G., Teuling, A. J., van Heerwaarden, C. C., and de Arellano, J. V.-G.: Mega-heatwave temperatures due to combined soil desiccation and atmospheric heat accumulation, Nat. Geosci., 7, 345-349, https://doi.org/10.1038/NGEO2141, 2014a.

Miralles, D. G., van den Berg, M. J., Gash, J. H., Parinussa, R. M., de Jeu, R. A. M., Beck, H. E., Holmes, T. R. H., Jiménez, C., Verhoest, N. E. C., Dorigo, W. A., Teuling, A. J., and Dolman, A. J.: El Niño-La Niña cycle and recent trends in continental evaporation, Nat. Clim. Change, 4, 122-126, https://doi.org/10.1038/NCLIMATE2068, 2014b.

Mohr, K. I., Famiglietti, J. S., Boone, A., and Starks, P. J.: Modeling soil moisture and surface flux variability with an untuned land surface scheme: a case study from the Southern Great Plains 1997 Hydrology Experiment, J. Hydrometeorol., 1, 154-169, 2000. 
Moradkhani, H., DeChant, C. M., and Sorooshian, S.: Evolution of ensemble data assimilation for uncertainty quantification using the particle filter-Markov Chain Monte Carlo method, Water Resour. Res., 48, W2520, https://doi.org/10.1029/2012WR012144, 2012.

Munier, S., Polebistki, A., Brown, C., Belaud, G., and Lettenmaier, D. P.: SWOT data assimilation for operational reservoir management on the upper Niger River Basin, Water Resour. Res., 51, 554-575, https://doi.org/10.1002/2014WR016157, 2014.

Munier, S., Carrer, D., Albergel, C., and Calvet, J. C.: Satellite Leaf Area Index: global scale analysis of the tendencies per vegetation type over the last 17 years, Remote Sens. Environ., submitted, 2017.

Muñoz, A. A., Barichivich, J., Christie, D. A., Dorigo, W., González-Reyes, A., González, M. E., Lara, A., Sauchyn, D., and Villalba, R Patterns and drivers of Araucaria araucana forest growth along a biophysical gradient in the northern Patagonian Andes: linking tree rings with satellite observations of soil moisture, Austral. Ecol., 39, 158-169, https://doi.org/10.1111/aec.12054, 2014.

Nash, J. E. and Sutcliffe, V.: River forecasting through conceptual models, J. Hydrol., 10, 282-290, 1970.

Noilhan, J. and Mahfouf, J.-F.: The ISBA land surface parameterisation scheme, Global Planet. Change, 13, 145-159, 1996.

Oki, T. and Sud, Y. C.: Design of Total Runoff Integrating Pathways (TRIP), a global river chanel network, Earth Interact., 2, 1-36, 1998.

Parrens, M., Mahfouf, J.-F., Barbu, A. L., and Calvet, J.-C.: Assimilation of surface soil moisture into a multilayer soil model: design and evaluation at local scale, Hydrol. Earth Syst. Sci., 18, 673-689, https://doi.org/10.5194/hess-18-673-2014, 2014.

Quintana-Segui, P., Le Moigne, P., Durand, Y., Martin, E., Habets, F., Baillon, M., Canellas, C., Franchisteguy, L., and Morel, S.: Analysis of near surface atmospheric variables: validation of the SAFRAN analysis over France, J. Appl. Meteorol. Clim., 47, 92-107, 2008.

Reichle, R., Walker, J., Koster, R., and Houser, P.: Extended vs. ensemble Kalman filtering for land data assimilation, J. Hydrometeorol., 3, 728-740, 2002.

Reichle, R. H. and Koster, D.: Bias reduction in short records of satellite soil moisture, Geophys. Res. Lett., 31, L19501, https://doi.org/10.1029/2004GL020938, 2004.

Reichstein, M., Bahn, M., Ciais, P., Frank, D., Mahecha, M. D., Seneviratne, S. I., Zscheischler, J., Beer, C., Buchmann, N., Frank, D. C., Papale, D., Rammig, A., Smith, P., Thonicke, K., van der Velde, M., Vicca, S., Walz, A., and Wattenbach, M.: Climate extremes and the carbon cycle, Nature, 500, 287-295, 2013.

Richards, L. A.: Capillary conduction of liquids in porous mediums, Physics, 1, 318-333, 1931.

Ridler, M.-E., Madsen, H., Stisen, S., Bircher, S., and Fensholt, R.: Assimilation of SMOS-derived soil moisture in a fully integrated hydrological and soil-vegetation atmosphere transfer model in Western Denmark, Water Resour. Res., 50, 8962-8981, 2014.

Rüdiger, C., Albergel, C., Mahfouf, J.-F., Calvet, J.-C., and Walker, J. P.: Evaluation of Jacobians for Leaf Area Index data assimilation with an extended Kalman filter, J. Geophys. Res., 115, D09111, https://doi.org/10.1029/2009JD012912, 2010.

Sabater, J. M., Rudiger, C., Calvet, J.-C., Fritz, N., Jarlan, L., and Kerr, Y.: Joint assimilation of surface soil moisture and LAI observations into land surface model, Agr. Forest Meteorol., 148, 1362-1373, https://doi.org/10.1016/j.agrformet.2008.04.003, 2008.

Schellekens, J., Dutra, E., Martínez-de la Torre, A., Balsamo, G., van Dijk, A., Sperna Weiland, F., Minvielle, M., Calvet, J.-C., Decharme, B., Eisner, S., Fink, G., Flörke, M., Peßenteiner, S., van Beek, R., Polcher, J., Beck, H., Orth, R., Calton, B., Burke, S., Dorigo, W., and Weedon, G. P.: A global water resources ensemble of hydrological models: the eartH2Observe Tier-1 dataset, Earth Syst. Sci. Data, 9, 389-413, https://doi.org/10.5194/essd-9-389-2017, 2017.

Scipal, K., Drusch, M., and Wagner, W.: Assimilation of a ERS scatterometer derived soil moisture index in the ECMWF numerical weather prediction system, Adv. Water Resour., 31, 1101-1112, https://doi.org/10.1016/j.advwatres.2008.04.013, 2008.

Seneviratne, S. I., Corti, T., Davin, E. L., Hirschi, M., Jaeger, E. B., Lehner, I., Orlowsky, B., and Teuling, A. J.: Investigating soil moisture-climate interactions in a changing climate: a review, Earth-Sci. Rev., 99, 125-161, 2010.

Slevin, D., Tett, S. F. B., Exbrayat, J.-F., Bloom, A. A., and Williams, M.: Global evaluation of gross primary productivity in the JULES land surface model v3.4.1, Geosci. Model Dev., 10, 2651-2670, https://doi.org/10.5194/gmd-10-2651-2017, 2017.

Smith, P. C., De Noblet-Ducoudré, N., Ciais, P., Peylin, P., Viovy, N., Meurdesoif, Y., and Bondeau, A.: European-wide simulations of croplands using an improved terrestrial biosphere model: phenology and productivity, J. Geophys. Res., 115, G01014, https://doi.org/10.1029/2008JG000800, 2010a.

Smith, P. C., Ciais, P., Peylin, P., De Noblet-Ducoudré, N., Viovy, N., Meurdesoif, Y., and Bondeau, A.: Europeanwide simulations of croplands using an improved terrestrial biosphere model: 2. Interannual yields and anomalous $\mathrm{CO}_{2}$ fluxes in 2003, J. Geophys. Res., 115, G04028, https://doi.org/10.1029/2009JG001041, 2010b.

Su, C. H., Zhang, J., Gruber, A., Parinussa, R., Ryu, D., W. T., Crow and Wagner, W.: Error decomposition of nine passive and active microwave satellite soil moisture data sets over Australia, Remote Sens. Environ., 182, 128-140, https://doi.org/10.1016/j.rse.2016.05.008, 2016.

Szczypta, C., Calvet, J.-C., Maignan, F., Dorigo, W., Baret, F., and Ciais, P.: Suitability of modelled and remotely sensed essential climate variables for monitoring Euro-Mediterranean droughts, Geosci. Model Dev., 7, 931-946, https://doi.org/10.5194/gmd-7931-2014, 2014

Traore, A. K., Ciais, P., Vuichard, N., Poulter, B., Viovy, N., Guimberteau, M., Jung, M., Myneni, R., and Fisher, J. B.: Evaluation of the ORCHIDEE ecosystem model over Africa against 25 years of satellite-based water and carbon measurements, J. Geophys. Res.-Biogeo., 119, 1554-1575, https://doi.org/10.1002/2014JG002638, 2014.

Van der Molen, M. K., Dolman, A. J., Ciais, P., Eglin, T., Gobron, N., Law, B. E., Meir, P., Peters, W., Phillips, O. L., Reichstein, M., Chen, T., Dekker, S. C., Doubková, M., Friedl, M. A., Jung, M., van den Hurk, B. J. J. M., de Jeu, R. A. M., Kruijt, B., Ohta, T., Rebel, K. T., Plummer, S., Seneviratne, S. I., Sitch, S., Teuling, A. J., van der Werf, G. R., and Wang, G.: Drought and ecosystem carbon cycling, Agr. Forest Meteorol., 151, 765-773, 2012. 
van der Schrier, G., Barichivich, J., Briffa, K. R., and Jones, P. D.: A scPDSI-based global data set of dry and wet spells for 19012009, J. Geophys. Res.-Atmos., 118, 4025-4048, 2013.

Vergnes, J.-P. and Decharme, B.: A simple groundwater scheme in the TRIP river routing model: global off-line evaluation against GRACE terrestrial water storage estimates and observed river discharges, Hydrol. Earth Syst. Sci., 16, 3889-3908, https://doi.org/10.5194/hess-16-3889-2012, 2012.

Vergnes, J.-P., Decharme, B., and Habets, F.: Introduction of groundwater capillary rises using subgrid spatial variability of topography into the ISBA land surface model, J. Geophys. Res.-Atmos., 119, 11065-11086, https://doi.org/10.1002/2014JD021573, 2014.

Voldoire, A., Decharme, B., Pianezze, J., Lebeaupin Brossier, C., Sevault, F., Seyfried, L., Garnier, V., Bielli, S., Valcke, S., Alias, A., Accensi, M., Ardhuin, F., Bouin, M.-N., Ducrocq, V., Faroux, S., Giordani, H., Léger, F., Marsaleix, P., Raynaud, R., Redelsperger, J.-L., Richard, E., and Riette, S.: The seamless and multi-model coupling between atmosphere, land, hydrology, ocean, waves and sea-ice models based on SURFEX surface model using OASIS3-MCT, Geosci. Model Dev. Discuss., https://doi.org/10.5194/gmd-2017-91, in review, 2017.

Wagner, W., Lemoine, G., and Rott, H.: A method for estimating soil moisture from ERS scatterometer and soil data, Remote Sens. Environ., 70, 191-207, 1999.

Wagner, W., Dorigo, W., de Jeu, R., Fernandez, D., Benveniste, J., E. Haas and Ertl, M.: Fusion of active and passive microwave observations to create an essential climate variable data record on soil moisture,ISPRS Annals of Photogrammetry, Remote Sensing and Spatial Information Sciences, 25 August, 1 September 2012, Volume I-7, 315-321, 2012.

Wanders, N., Karssenberg, D., de Roo, A., de Jong, S. M., and Bierkens, M. F. P.: The suitability of remotely sensed soil moisture for improving operational flood forecasting, Hydrol. Earth Syst. Sci., 18, 2343-2357, https://doi.org/10.5194/hess-18-23432014, 2014.
Wang, L., D’Odorico, P., Evans, J. P., Eldridge, D. J., McCabe, M. F., Caylor, K. K., and King, E. G.: Dryland ecohydrology and climate change: critical issues and technical advances, Hydrol. Earth Syst. Sci., 16, 2585-2603, https://doi.org/10.5194/hess-162585-2012, 2012.

Weedon, G. P., Gomes, S., Viterbo, P., Shuttleworth, W. J., Blyth, E., Österle, H., Adam, J. C., Bellouin, N., Boucher, O., and Best, M.: Creation of the WATCH forcing data and its use to assess global and regional reference crop evaporation over land during the twentieth century, J. Hydrometeorol., 12, 823-848, https://doi.org/10.1175/2011JHM1369.1, 2011.

Weedon, G. P., Balsamo, G., Bellouin, N., Gomes, S., Best, M. J., and Viterbo, P.: The WFDEI meteorological forcing data set: WATCH Forcing data methodology applied to ERAinterim reanalysis data, Water Resour. Res., 50, 7505-7514, https://doi.org/10.1002/2014WR015638, 2014.

Wieder, W. R., Boehnert, J., Bonan, G. B., and Langseth, M.: Regridded Harmonized World Soil Database v1.2. Data set, Oak Ridge National Laboratory Distributed Active Archive Center, Oak Ridge, Tennessee, USA, available at: http://daac.ornl.gov, 2014.

Zhang, Y., Peña-Arancibia, J. L., McVicar, T. R., Chiew, F. H. S., Vaze, J., Liu, C., Lu, X., Zheng, H., Wang, Y., Liu, Y. Y., Miralles, D. G., and Pan, M.: Multi-decadal trends in global terrestrial evapotranspiration and its components, Sci. Rep.-UK, 6 , 19124, https://doi.org/10.1038/srep19124, 2016. 